\title{
Recovery of creosote from used railroad ties by thermal desorption
}

Pyoungchung Kim ${ }^{1 *}$, Jeff Lloyd ${ }^{2}$, Jae-Woo Kim² ${ }^{2}$ Nourredine Abdoulmoumine ${ }^{3}$ and Nicole Labbé $^{1^{*}}$

${ }^{1}$ Center for Renewable Carbon, the University of Tennessee, 2506 Jacob Dr., Knoxville, TN 37996, USA

${ }^{2}$ Nisus Corp., 100 Nisus Dr. Rockford, TN 37853, USA

${ }^{3}$ Biosystems Engineering \& Soil Science, the University of Tennessee, 2506 E.J. Chapman Dr. Knoxville, TN 37996, USA

${ }^{*}$ Corresponding authors.

Pyoungchung Kim: pkim1@utk.edu, Phone: (865) 974-5086. Fax: (865) 946-1109

Nicole Labbé: nlabbe@utk.edu, Phone: (865) 946-1126. Fax: (865) 946-1109

\begin{abstract}
Used creosote-treated wood ties were thermally treated between 250 and $350{ }^{\circ} \mathrm{C}$ to recover preservative and upgrade the wood to provide an improved quality biomass for thermochemical processes. With thermal treatments ranging from 250 to $300^{\circ} \mathrm{C}$, the amounts of creosote, mostly consisting of polycyclic aromatic hydrocarbons (PAHs), recovered were from 47 to $79 \%$ of total creosote present in the used ties. Thermal treatment at $350{ }^{\circ} \mathrm{C}$ recovered $97 \%$ of total $\mathrm{PAH}$ compounds. Larger amounts of PAHs with higher molecular weights (HMWs) and lower vapor pressures (LVP) were recovered at elevated temperatures. Temperature above $300{ }^{\circ} \mathrm{C}$ decomposed the wood matrix, with a mass loss ranging between 50 to $63 \mathrm{wt} \%$ and produced large amounts of light organics, anhydrosugars, and phenolic compounds that would contaminate the recovered creosote. Our study concluded that thermal treatment ranging between 275 and $300{ }^{\circ} \mathrm{C}$ would be preferred to recover preservative for recycling and improve the wood quality,
\end{abstract}


i.e., high carbon content and caloric value, and low hazardous pollutants (creosote residues) for thermochemical processes such as pyrolysis or gasification. These findings suggest that the proposed approach could be a commercially viable and environmentally beneficial alternative to landfill for used railroad ties.

Keywords:

Creosote; Thermal desorption; thermochemical processes; used railroad ties; polycyclic aromatic hydrocarbons.

\section{Introduction}

Creosote is a fungicide and insecticide used as a wood preservative and primarily to treat railroad ties, utility poles, piling and bridge timbers to provide long-term resistance to biodegradation. Creosote is a distillation product of coal tar derived by the high temperature carbonization of bituminous coal [1]. It is a complex mixture typically composed of approximately $85 \%$ polycyclic aromatic hydrocarbons (PAHs) and $2-17 \%$ phenolics, the composition of which varies across sources and manufactures [2]. The U.S. Environmental Protection Agency (EPA) has determined that approximately $20-40 \%$ of the total weight of creosote can be attributed to sixteen PAHs, which are priority pollutants and potential carcinogens such as benzo[a]pyrene [3].

In the U.S., there are $700-800$ million railroad ties in service in railroad tracks with approximately 20 million ties being replaced annually [4]. Over 95\% of railroad ties produced are wood ties treated by impregnation with creosote and coal tar, or creosote and oil blends [4]. On average, $88 \mathrm{~kg} / \mathrm{m}^{3}$ of creosote is impregnated into a wood tie and $65 \%$ of the creosote are 
still retained after 35 years of typical service [5]. After their service life, over $80 \%$ of used wood ties are repurposed as fuel for industrial wood-fired boilers and gasification facilities to produce combined heat and power [6]. However, under the U.S. EPA's 2014 NHSM (Non Hazardous Secondary Materials) rule, treated wood such as railroad ties are newly classified as waste [7]. As a result, many treated wood ties previously used as biomass fuel will be landfilled. In addition to the considerable landfill space that will be required to dispose of used ties, landfill-disposed biomass produces greenhouse gases (GHG) such as carbon dioxide and methane [8].

As an alternative to landfilling, a few research groups have used fast pyrolysis to produce a liquid fraction containing creosote and wood-decomposed bio-oil as a bio-oil preservative [9], which is problematic as the mixture is not EPA registered and is difficult to separate into intermediate sources for chemicals, fuels, and biomaterials [10]. In our previous study [11], we demonstrated the feasibility of creosote recovery from used wood ties with minimum decomposition of the wood matrix via a thermal desorption process. Our study was carried out at various temperatures using analytical thermochemical analysers such as thermogravimetric spectrometry (TGA) and pyrolysis-gas chromatography/mass spectrometry (Py-GC/MS). The objective of this study was to investigate the recovery yield and composition of creosote desorbed from used wood ties under various thermal treatment conditions using a lab-scale fixed bed reactor with condensers. This study aim at quantifying creosote compounds as well as the decomposition of wood matrix during the various thermal treatment conditions. This study also addresses specific challenges associated with thermally treated wood ties as a quality feedstock for thermochemical processes such as pyrolysis, co-generation, or gasification. 


\section{Material and methods}

\subsection{Material}

A used creosote-treated railroad tie was obtained from National Salvage \& Services Corporation (Bloomington, IN, USA). The tie was ground into less than $2 \mathrm{~mm}$ particle sizes with a knife mill and further sieved to obtain a fraction with particle sizes between $0.45-2 \mathrm{~mm}$. This latter fraction was used for all experiments.

\subsection{Experimental set up and procedure}

The thermal treatment experiment was carried out in a bench-scale fixed-bed reactor equipped with a condensation system (Fig. 1). The reactor was made of a $1.2 \mathrm{~kW}$ vertical furnace (MTI corp.) with a $300 \mathrm{~mm}$ long heating zone and a cylindrical quartz tube (internal diameter $47 \mathrm{~mm}$, length $610 \mathrm{~mm}$ ) with a sample holder consisting of porous stainless steel basket (pore size 0.37 mm, diameter $32 \mathrm{~mm}$, length $250 \mathrm{~mm}$ ) into which the sample was loaded. For each run, $30 \mathrm{~g}$ wood tie sample were loaded into the porous holder, inserted into the bottom of the quartz tube, away from the heated zone. A constant nitrogen purge gas at a flow rate of $4 \mathrm{~L} / \mathrm{min}$ was maintained. The furnace was then heated to desired temperature $\left(250,275,300,325\right.$, or $\left.350{ }^{\circ} \mathrm{C}\right)$ at a heating rate of $10^{\circ} \mathrm{C} / \mathrm{min}$. Once the furnace reached the desired temperature, the sample holder was lifted up into the isothermal zone of the quartz tube in the furnace, where the wood tie sample was thermally treated for a 30 min residence time. After 30 min, the sample holder was lowered to the bottom of the quartz tube for cooling under continuous nitrogen flow. The vapors produced during the thermal desorption were transferred by the purge gas from the reactor into a series of liquid nitrogen-cooled condensers. The condensation section was comprised of four dewar-type glass condensers, which were filled up with liquid nitrogen to cool 
down the condensers (Fig. 1). Species that condensed on the wall of the condensers were recovered and fractionated as discussed in the next section.

\subsection{Characterization}

\subsubsection{Liquid fraction}

Vapors condensed on the walls of the glass condensers were recovered either with $250 \mathrm{~mL}$ methanol (Fraction \#1) or $250 \mathrm{~mL}$ dichloromethane $\left(\mathrm{CH}_{2} \mathrm{Cl}_{2}\right)$ and followed by $250 \mathrm{~mL}$ of deionized water (Fraction \#2). Fraction \#1 was used to determine the water content and to identify condensable species using gas chromatography/mass spectrometry (GC/MS) while Fraction \#2 was used to quantify the amount of creosote and wood-derived components. Each experiment was conducted in triplicate.

\subsubsection{Characterization of liquid fraction \#1}

Water content in the liquid fraction \#1 (methanol fraction) was measured by Karl Fischer titration (Metrohm 787 KF Titrino) according to the American Society for Testing and Materials (ASTM D4377). The chemical composition of this fraction was determined by GC/MS (Perkin Elmer Clarus 680 Gas Chromatograph coupled with a Clarus SQ 8C Mass Spectrometer). A 1.0 $\mu L$ aliquot of solution was injected into the GC with the injection port maintained at $270{ }^{\circ} \mathrm{C}$. The compounds were then separated using an Elite 1701 capillary column (60 m x $0.25 \mathrm{~mm} \mathrm{ID} \mathrm{x}$ $0.25 \mu \mathrm{m}$ film thickness) with the following temperature program: $5 \mathrm{~min}$ at $50{ }^{\circ} \mathrm{C}, 5{ }^{\circ} \mathrm{C} \min ^{-1}$ to $280^{\circ} \mathrm{C}$ and $20 \mathrm{~min}$ at $280^{\circ} \mathrm{C}$. Ultra-high pure helium was used as the carrier gas $(1 \mathrm{~mL} / \mathrm{min})$. The separated compounds were analyzed using a mass spectrometer (MS) with a source temperature of $270{ }^{\circ} \mathrm{C}$ and electron ionization of 70 . Approximately 74 compounds with a peak to noise 
height ratio $\geq 10: 1$ were identified by comparison with the NIST mass spectra data library of fragmentation patterns.

\subsubsection{Characterization of liquid fraction \#2}

The liquid fraction \#2 (dichloromethane-water fraction) was further fractionated into four groups (PAHs, phenolics, light organics and anhydrosugars) that correspond to creosote and woodderived compounds. The fractionation scheme is based on creosote extraction [12] and bio-oil fractionation $[13,14]$ methods and is outlined in Fig. 2. In this method, $500 \mathrm{~mL}$ of fraction $\# 2$ was placed in a $1000 \mathrm{~mL}$ separatory funnel and adjusted to $\mathrm{pH} 14$ with sodium hydroxide $(\mathrm{NaOH})$. All samples were extracted three times using dichloromethane (DCM), resulting in the transfer of non-polar creosote compounds including PAHs to the organic phase. The quantity of PAH compounds in the organic phase was determined gravimetrically after evaporating DCM using a rotary evaporator (IKA) and vacuum-drying at $40{ }^{\circ} \mathrm{C}$. The aqueous phase, which contains lignin- and sugar-derived compounds from the wood matrix, was adjusted to $\mathrm{pH} 2$ with hydrochloric acid $(\mathrm{HCl})$ and extracted with DCM three times resulting in the transfer of ligninderived phenolics in the organic phase. The aqueous phase was further extracted with diethyl ether to transfer light organics in the ether-soluble fraction and anhydrosugars in the etherinsoluble fraction. The light organics, anhydrosugars and phenolic fractions were further vacuum-dried at $40{ }^{\circ} \mathrm{C}$ and weighed.

\subsubsection{Solid fraction}

Water content in the solid fraction before and after thermal treatment was measured by the Karl Fischer titration method using a 2: $1(\mathrm{v} / \mathrm{v} \%)$ mixture of methanol: chloroform with a titrant of hydranal composite 5K solution [15]. A thermogravimetric analyzer (Pyris 1 TGA, PerkinElmer) was used to evaluate the thermally treated wood ties with the temperature increasing from 30 to 
$800{ }^{\circ} \mathrm{C}$ at $10{ }^{\circ} \mathrm{C} / \mathrm{min}$ and holding for $10 \mathrm{~min}$ at $800{ }^{\circ} \mathrm{C}$ under $20 \mathrm{~mL} / \mathrm{min}$ of nitrogen gas flow. Proximate analysis including moisture content, ash content, volatile matter, and fixed carbon of the raw and thermally treated wood ties was determined following the ASTM D 1762-8. Ultimate analysis including carbon, hydrogen, and nitrogen was measured using a CHN analyser (2400 Series II CHNS/O, PerkinElmer). The higher heating value (HHV) of each thermally treated sample was calculated using an ordinary least-squares regression method [16]. Energy retained (HHV retained, \%), defined as the amount of energy conserved in the solid part after the thermal treatment, was calculated by equations 1 and 2 [17]:

$$
\begin{aligned}
& M_{\text {retained }}(\%)=100 \times \frac{m_{t}}{m_{i}} \\
& H H V_{\text {retained }}(\%)=M_{\text {retained }} \times \frac{H H V_{t}}{H H V_{i}}
\end{aligned}
$$

where, $M_{\text {retained }}=$ mass retained after thermal treatment in percentage (\%); $m_{t}=$ mass of thermally treated sample; $m_{i}=$ mass of raw sample; $H H V_{t}=\mathrm{HHV}$ of thermally treated sample; $H H V i=$ HHV of raw sample.

PAHs in the solid fraction of the raw and thermally treated wood ties were extracted with DCM using an accelerated solvent extractor (ASE 350, Dionex Corp.) at $100{ }^{\circ} \mathrm{C}$ and 9 cycles [18]. Extracted solvent $(180 \mathrm{~mL})$ was placed in a $1000 \mathrm{~mL}$ separatory funnel and subjected to fractionated scheme outlined in Fig.2. All thermal treatments were performed in triplicate.

\section{Results and discussion}

\subsection{Thermal treatment}

\subsubsection{Mass loss}

Used creosote wood tie samples were thermally treated at $250,275,300,325$, and $350{ }^{\circ} \mathrm{C}$ for a 30 min to desorb the creosote using a fixed bed reactor illustrated in Fig. 1. The mass loss 
of the sample after thermal treatment was $13 \mathrm{wt} \%$ at $250{ }^{\circ} \mathrm{C}$. As temperature increased, the mass loss increased to $20 \mathrm{wt} \%$ at $275{ }^{\circ} \mathrm{C}, 36 \mathrm{wt} \%$ at $300{ }^{\circ} \mathrm{C}, 50 \mathrm{wt} \%$ at $325{ }^{\circ} \mathrm{C}$, and $63 \mathrm{wt} \%$ at $350{ }^{\circ} \mathrm{C}$ (Fig. 3). The mass loss in this study was comparable to the data obtained with a thermogravimetric analyser (TGA) in our previous study [11] demonstrating that the experimental setup of the lab-scale reactor was suitable for thermal treatment of the wood tie samples. It also suggests that thermal desorption of creosote-treated wood ties is scalable. The moisture content in the untreated and treated ties was measured by two techniques: Karl Fischer titration (KFT) and ASTM methods. As shown in Table 1, the moisture content determined by the ASTM method was always higher when compared to the KFT method. This observation suggests that an elevating temperature, as it is done in the ASTM moisture content method, results in gradual desorption of creosote thus leading to overestimating the moisture content of the ties.

\subsubsection{Thermogravimetric analysis}

The thermogravimetric profiles demonstrated the level of desorption of creosote and decomposition of wood matrix of the raw and thermally treated samples (Fig. 4). The TG thermograms (Fig. 4a) of the untreated sample exhibited a gradual increase of mass loss in the $\mathrm{T} 1$ and $\mathrm{T} 2$ regions followed by a drastic increase in T3 region and then a slow increase to $800{ }^{\circ} \mathrm{C}$. The corresponding derivative of the thermograms (DTG) curve (Fig. 4b) of the untreated sample showed a small peak from the gradual mass loss in the T1 region associated with water removal and desorption of creosote. This observation is consistent with moisture content results shown in Table 1 and indicates that moisture content of creosote-treated ties is more accurately measured by Karl Fischer titration than the conventional oven drying technique due to desorption of creosote during the analysis. The broad peak in the T2 region was predominately associated with 
mass loss by thermal desorption of creosote compounds with broad boiling points from 180 to $496{ }^{\circ} \mathrm{C}$ for the untreated sample. Finally, the major peaks in the T3 region represent the decomposition of cellulose, hemicellulose, and lignin in the wood matrix [19].

In contrast, the thermograms (Fig. 4a) of the thermally treated samples showed no change in mass in $\mathrm{T} 1$ and $\mathrm{T} 2$ regions but a drastic increase of mass loss at temperature ranging from 250 to $390{ }^{\circ} \mathrm{C}$ (T3 region) with a shift in initial degradation severity as treatment temperature increased. The DTG curves of treated ties at $250{ }^{\circ} \mathrm{C}$ exhibited a maxima peak at $370{ }^{\circ} \mathrm{C}$ with a shoulder peak at $318{ }^{\circ} \mathrm{C}$ in the $\mathrm{T} 3$ region. Interestingly, this shoulder peak at $318{ }^{\circ} \mathrm{C}$ was observed to be smaller than that of the untreated sample, suggesting that creosote compounds were also desorbed in this temperature region. As the wood ties were thermally treated from 250 to $300^{\circ} \mathrm{C}$, the shoulder peak at $318{ }^{\circ} \mathrm{C}$ gradually decreased and disappeared for the $300{ }^{\circ} \mathrm{C}$-treated sample. The disappearance of the shoulder peak is associated with degradation of cellulose as well as hemicellulose in the wood matrix. The treated samples above $300{ }^{\circ} \mathrm{C}$ exhibited a reduction of the maxima peak at $370{ }^{\circ} \mathrm{C}$ indicative of a significant decomposition of cellulose.

\subsection{Liquid products}

\subsubsection{Creosote recovery}

Creosote compounds and wood-decomposed products in the liquid fraction collected from the condensers were analyzed using GC/MS before and after solvent fractionation. In total, 44 creosote compounds were identified by GC/MS (Table 2 and Supporting information Fig. A1). These creosote compounds have a broad spectrum of molecular weights (MW) ranging from 128 to $252 \mathrm{~g} / \mathrm{mol}$, boiling points from 218 to $495{ }^{\circ} \mathrm{C}$, and vapor pressures from 12.3 to $10^{-6} \mathrm{~Pa}$ at $25{ }^{\circ} \mathrm{C}$ (Supporting Information Table A1). The recovered creosote contained mostly polycyclic 
aromatic hydrocarbon (PAHs) compounds such as acenaphthylene, dibenzofuran, fluorene, phenanthrene, anthracene, benzo[def]fluorene, fluoranthene, pyrene, chrysene, and benz[a]anthracene and other PAHs, indicating that creosote compounds recovered from used wood ties were distillated from coal tar [20].

Upon thermal treatment at $250{ }^{\circ} \mathrm{C}, 47 \%$ (5.1 of $11.1 \mathrm{wt} \%$ ) of total PAHs present in the wood tie samples were recovered as illustrated in Fig. 5a. The samples treated at 275 and $300{ }^{\circ} \mathrm{C}$ desorbed $65 \%$ (7.2 of $11.1 \mathrm{wt} \%$ ) and $79 \%$ (8.8 of $11.1 \mathrm{wt} \%$ ) of PAHs, respectively. The recovery fractions of PAHs were $89 \%$ (9.9 of $11.1 \mathrm{wt} \%)$ at $325{ }^{\circ} \mathrm{C}$ and $97 \%(10.7$ of $11.1 \mathrm{wt} \%)$ at $350{ }^{\circ} \mathrm{C}$. Over $80 \%$ of PAHs present in the used railroad ties were desorbed at temperature above $300{ }^{\circ} \mathrm{C}$. In order to determine the distribution of PAH compounds recovered from the liquid fraction at different thermal treatment conditions, PAH compounds were categorized into eight groups based on their vapor pressures (v.p. Pa at $25{ }^{\circ} \mathrm{C}$ ). For example; G1 ranged between 8.3 and 12.3 Pa, G2 between $1.7-2.5 \mathrm{~Pa}$, G3 at $10^{-1} \mathrm{~Pa}$, G4 at $10^{-2} \mathrm{~Pa}$, G5 at $10^{-3} \mathrm{~Pa}$, G6 at $10^{-4} \mathrm{~Pa}$, G7 at $10^{-5} \mathrm{~Pa}$, and G8 at $10^{-6} \mathrm{~Pa}$ (Fig. $5 \mathrm{~b}$ and Supporting information Table A1). The classification was based on vapor pressures due to the fact that the volatilization of PAHs from treated wood in service depends on temperature and vapor pressure. In particular, vapor pressure is strongly positively correlated with the desorption rates of PAHs [21]. The GC/MS peak area distribution percentage of PAHs with broad vapor pressures (Fig. 5b) showed that the $250{ }^{\circ} \mathrm{C}$ treated sample released more PAHs with lower molecular weights and higher vapor pressures. As temperature increased, so did the amount of PAHs with higher molecular weight and lower vapor pressures (Fig. 5b). The recovery of PAHs from the $250{ }^{\circ} \mathrm{C}$-treated wood tie had the highest proportion (72\%) of PAHs with high vapor pressures, ranging between $10^{-3}-12.3 \mathrm{~Pa}$. These PAHs were mostly naphthalene, methyl naphthalene, dimethyl naphthalene, 
methylbiophenyl, dibenzofuran, biophenyl, acenaphthylene, methyldiobenzofuran, phenyl naphthalene, fluorene, methyl phenanthrene, benzo[def]fluorene, and fluoranthene (Fig. 5c - 5j). As temperature increased, the recovery of PAHs with higher vapor pressures diminished, whereas that of PAHs with higher molecular weight and lower vapor pressures ranging between $10^{-6}$ and $10^{-4} \mathrm{~Pa}$ (Fig. 5b), like anthracene, carbazole, pyrene, chrysene, 2,3-benzo[c]fluorene, benzo[a]anthracene, benzo[k]fluoranthene, benzo[l]fluoranthene, and benzo[a]pyrene gradually increased (Fig. 5c - 5j). In particular, PAHs such as benzo[a]pyrene and benzo[c]pyrene with a boiling point of $495{ }^{\circ} \mathrm{C}$ and vapor pressure of $1.6 \times 10^{-6}$ Pa at $25{ }^{\circ} \mathrm{C}$ were observed at thermal treatment above $300^{\circ} \mathrm{C}$ albeit in small quantities. PAH compounds recovered from the thermally treated wood ties at temperature above $300{ }^{\circ} \mathrm{C}$ had a similar distribution of PAHs present in the untreated sample although traceable PAHs with vapor pressures ranging between $10^{-5}$ and $10^{-6}$ Pa still remained in the thermally treated wood ties. The distribution of individual PAH compounds recovered from the untreated and thermally treated wood ties at above $300{ }^{\circ} \mathrm{C}$ was compared to those of fresh PAHs in AWPA (American Wood Preservers' Association) standard creosotes derived from coal tar [20], AWPA creosote contains a significantly higher proportion of PAHs with lower molecular weights and higher vapor pressures $\left(10^{-3}-12.3 \mathrm{~Pa}\right)$ including naphthalene, methylnaphthalene, biophenyl, acenaphthylene, phenanthrene, and fluorene than our recovered PAHs. This indicates that PAH compounds evaporate or leach, or that physicochemical and biological degradative processes selectively degrade PAHs with lower molecular weights and higher vapor pressures during the service life of ties [22]. It could also reflect a change in creosote formulation from the original creosote/coal tar blends or creosote/oil blends. In any event, it is believed that recovered creosote could be amended with a slight addition of oil or creosote components if needed before being reused. 


\subsubsection{Decomposition of wood matrix}

The wood-decomposed products in the liquid fraction were analyzed using GC/MS after a solvent fractionation (Table 2 and Supporting information Fig. A1). Thermal treatment at $250{ }^{\circ} \mathrm{C}$ produced very small amounts of light organics, anhydrosugars, and phenolic compounds (Fig. A1) with acetic acid (2), levoglucosan (43), and several phenolic compounds (Fig.A1. and Table 2). The decomposition of the wood matrix started at temperature above $275^{\circ} \mathrm{C}$ producing high peak intensity of light oxygenated compounds, glycolaldehyde (1), acetic acid (2), hydroxyacetone (3) and low peak intensity of furans, furfural (10), 2(5H)-furanone (16), levoglucosan (43), and phenolic compounds such as o-guaiacol (19), 4-vinylguaiacol (25), isoeugenol (32), 4-methoxy-3-(methoxyemthyl)phenol (33), methoxyeugenol (41) with a slightly elevated amount of anhydrosugars and phenolic compounds. Acetic acid derived mostly from fragmented acetyl groups on pentosans in hemicellulose and from cellulose fragmentation reaction. These results demonstrated the drastic decomposition of hemicellulose and cellulose in the wood matrix at $275{ }^{\circ} \mathrm{C}$, which was confirmed by the significant reduction of the shoulder peak in the DTG curve (Fig. 4b.) Other light organics (glycolaldehyde and hydroxyacetone) are also products of hemicellulose and cellulose fragmentation reactions. Furanic compounds (furfural and 2(5H)-furanone) are known to be products of carbohydrate (cellulose and hemicellulose) dehydration. Anhydrosugar (levoglucosan) is a product from depolymerisation of cellulose [23] while phenolic compounds are derived from lignin. These results indicate that hemicellulose, cellulose, and lignin gradually decomposed with temperature; for example, hemicellulose breaks down in the temperature ranging between 220 and $315{ }^{\circ} \mathrm{C}$, cellulose between 240 and $360{ }^{\circ} \mathrm{C}$, and lignin between 240 and $360{ }^{\circ} \mathrm{C}$ [24]. Thermal treatment at $300{ }^{\circ} \mathrm{C}$ increased the amount of anhydrosugars and phenolic compounds (Fig. 6), with the presence of 
additional light organics (acetoxyacetic acid (6), methyl pyruvate (8)), anhydrosugars (1,4:3,6Dianhydro- $\alpha$-D-glucopyranose (24)), and various phenolic compounds. Thermal treatment at 325 and $350{ }^{\circ} \mathrm{C}$ produced a large amount of anhydrosugars such as levoglucosan and 1,4:3,6Dianhydro- $\alpha$-D-glucopyranose (dehydrated from levoglucosan) demonstrating that the drastic reduction of DTG maximum peak at $370{ }^{\circ} \mathrm{C}$ was associated with cellulose (Fig. 4b). Reaction water was calculated by first determining the total mass of water in the liquid fraction using Karl Fischer titration followed by subtracting the mass of water that contributed from moisture in the creosote-treated wood tie sample (Fig. 6). The yield of reaction water increased with temperature from 250 to $300{ }^{\circ} \mathrm{C}$ and reached a plateau of around 23 - $25 \mathrm{wt} \%$ at temperatures between $300-$ $350{ }^{\circ} \mathrm{C}$, demonstrating a dramatic increase of reaction water yield at $300^{\circ} \mathrm{C}$ at the expense of the decomposition of cellulose and hemicellulose by dehydration reaction [25, 26]. The products containing light organics, levoglucosan and monomeric phenolic compounds dissolved in the aqueous phase could be directly used as a potential substrate for an integrated pyrolysismicrobial electrolysis for hydrogen production or as intermediates to produce value-added chemicals [27].

\subsection{Solid products}

\subsubsection{Creosote residue in the thermally treated wood}

The amount of PAHs remaining in the thermally treated wood tie samples showed that the $250{ }^{\circ} \mathrm{C}$-treated sample still contained $45 \%$ (5.0 of $11.1 \mathrm{wt} \%$ ) of the total PAHs (Fig. 7a). As temperature increased, $29 \%$ of total PAHs remained in the $275{ }^{\circ} \mathrm{C}$-treated wood tie and decreased to $13 \%$ of PAHs in the $300{ }^{\circ} \mathrm{C}$-treated wood tie. The thermally treated wood tie 
sample at above $300{ }^{\circ} \mathrm{C}$ still contained very small amount of PAHs such as $8 \%$ in the $325{ }^{\circ} \mathrm{C}$ treated wood tie and $3 \%$ in the $350^{\circ} \mathrm{C}$-treated wood tie.

The distribution of the $\mathrm{PAH}$ compounds with different vapor pressures showed that as temperature increased from 250 to $350{ }^{\circ} \mathrm{C}$, the thermally treated samples had a higher proportion

of the PAH compounds with lower MWs and higher vapor pressures ranging between $10^{-4}$ and 12.3 Pa and a lower proportion of the PAHs with higher MWs and lower vaper pressures ranging between $10^{-5}$ and $10^{-6} \mathrm{~Pa}$ (Fig. $7 \mathrm{~b}-7 \mathrm{f}$ ). For example, samples treated with elevated temperature had a decreasing proportion of the PAHs with relatively higher vapor pressures ranging between $10^{-4}$ and 12.3 Pa such as acenaphthalene, phenanthrene, fluoranthene, anthracene, pyrene, methyl pyrene and chrysene and an increasing portion of the PAHs with relatively lower vapor pressures ranging between $10^{-5}$ and $10^{-6} \mathrm{~Pa}$ such as benzo[a]anthracene, benzo[b]fluoranthene, benzo[k]fluoranthene, benzo[1]fluoranthene, benzo[a]pyrene, and benzo[e]pyrene.

\subsubsection{Solid matrix characterization}

Wood tie samples thermally treated at different temperatures were characterized using proximate and ultimate analyses. The proximate analysis revealed the property changes in volatile matter (VM), fixed carbon (FC), and ash after thermal treatment. The VM content of creosote-treated sample was 86 wt\%, while its FC content was 14 wt\% (Table 1). As creosote-treated wood samples were thermally treated from 250 to $350{ }^{\circ} \mathrm{C}$, VM decreased from 79 to $40 \mathrm{wt} \%$, whereas FC increased from 17 to 52 wt\%, demonstrating a linear decrease of VM with increasing FC (Table 1 and Fig. 8a). The main elements in creosote-treated wood sample include carbon (C), hydrogen $(\mathrm{H})$, oxygen $(\mathrm{O})$, and to a lesser extent nitrogen $(\mathrm{N})$, which are important sources of heat in combustion. As the samples were thermally treated up to $350{ }^{\circ} \mathrm{C}$, carbon content increased from 46.6 to $65.0 \%$, while hydrogen and oxygen decreased from 5.7 to $3.8 \%$, and 
from 46.0 to $23.6 \mathrm{wt} \%$, respectively (Table 1). It is worth noting that lower amount of oxygen and moisture produced with an elevated thermal treatment enhances the calorific value of the thermally treated tie wood. The atom oxygen-to-carbon $(\mathrm{O} / \mathrm{C})$ and hydrogen-to carbon $(\mathrm{H} / \mathrm{C})$ ratios in the non-thermally treated sample was $0.7(\mathrm{O} / \mathrm{C})$ and $1.5(\mathrm{H} / \mathrm{C})$, respectively (Fig. 8b). After thermal treatment at $250{ }^{\circ} \mathrm{C}$, oxygen and hydrogen drastically decreased, indicative of a reduction of water produced mainly from the dehydration of the hydroxyls in cellulose and hemicellulose and evaporation of PAH compounds [28]. The van Krevelene diagram for the thermally treated wood from 250 to $350{ }^{\circ} \mathrm{C}$ followed a linear relationship with the atomic $\mathrm{H} / \mathrm{C}$ ratio and the atomic $\mathrm{O} / \mathrm{C}$ ratio (Fig. 8b), demonstrating the desorption of creosote compounds and decomposition of wood matrix. The higher heating value (HHV) of the non-thermally treated wood was approximately $17 \mathrm{MJ} / \mathrm{kg}$ (Fig. 8c). The thermal treatment from 250 to $350{ }^{\circ} \mathrm{C}$ induced an increase of HHVs from 19 to $23 \mathrm{MJ} / \mathrm{kg}$, which is closer to the HHV (25 - $35 \mathrm{MJ} / \mathrm{kg}$ ) of coal [29]. The energy retained (the total energy ratio between thermally treated wood and nonthermally treated wood) showed a gradual reduction from 93 to $87 \%$ at temperatures from 250 to $275{ }^{\circ} \mathrm{C}$ and a more drastic reduction from 75 to $49 \%$ at temperatures above $300{ }^{\circ} \mathrm{C}$ even though HHV is enhanced (Fig. 8c).

\subsection{Applications}

Based on the aforementioned results, it is important to consider temperature conditions regarding the trade-off between creosote recovery and upgradability of thermally treated wood tie material for market demands in subsequent thermochemical processes such as pyrolysis, co-generation, or gasification. One consideration to determine is the operational heating temperature needed to recover PAHs remaining in the used railroad ties. The PAHs recovery \% from used railroad ties 
exhibits a drastic linear increase to $65 \%$ with a drop of solid yield to $80 \mathrm{wt} \%$ at a temperature of $275{ }^{\circ} \mathrm{C}$, whereas a gradual linear increase of PAHs recovery from 79 to $97 \%$ with a drastic decrease of solid yield from 64 to $37 \mathrm{wt} \%$ at temperature from 300 to $350{ }^{\circ} \mathrm{C}$ (Fig. 3). In addition, heating temperatures between 250 and $275^{\circ} \mathrm{C}$ cause negligible hemicellulose degradation (Fig. 4), whereas heating temperatures above $300{ }^{\circ} \mathrm{C}$ show a drastic linear increase in yield of woodderived components with degradation of hemicellulose, cellulose and lignin (Fig. 9). It is believed that temperatures ranging between 250 and $275{ }^{\circ} \mathrm{C}$ can recover a high purity of PAHs fraction with relatively low vapor pressures and molecular weights albeit with lower PAH recovery. At temperatures above $300{ }^{\circ} \mathrm{C}$, it is possible to recover most $\mathrm{PAH}$ compounds in the wood. However, at such high temperatures significant quantities of carbohydrate and ligninderived compounds will be mixed with the recovered PAHs, which could require further separation. Another consideration is the optimum operational temperature for the improvement of the thermally treated wood for downstream processing. Thermally treated tie-derived wood could be a potential source suitable for thermochemical conversion. Our study demonstrated that thermally treated tie-derived wood can avoid many limitations associated with the non-thermally treated wood, in a way similar to a torrefaction process [29], containing high carbon content, low O/C ratio, enhanced caloric values (19-23 MJ/kg), as well as low hazardous creosote residues. In particular, thermal treatment at $275{ }^{\circ} \mathrm{C}$ and $300{ }^{\circ} \mathrm{C}$ caused the energy retained in the wood to drop from 87 to $75 \%$ and the HHV to increase between 19.6 and $20.4 \mathrm{MJ} / \mathrm{kg}$ (Fig. 9). This may be enough for tie-derived wood to provide a quality biomass for subsequent thermochemical processes such as pyrolysis, gasification and co-generation. For example, there would be a reduction in fossil fuel derived carbon dioxide (as the creosote would be re-used and not be burned), and the thermally treated wood ties could be a high quality feedstock for pyrolysis in a 
similar way to torrefied biomass treated at $200-300{ }^{\circ} \mathrm{C}$ in an inert atmosphere. Torrefaction improves a quality of biomass associated with grindability, hydrophobicity and energy density, making it more favorable for further processes such as combustion, gasification, and pyrolysis [30]. Furthermore, pyrolysis of torrefied biomass produces a high quality of bio-oil with low water content, acidity, and high pyrolytic lignin compounds as an intermediate source for a downstream refinery process [31]. Conversely, temperatures above $300{ }^{\circ} \mathrm{C}$ cause an energy retained to drop to 60 and $49 \%$ but with PAH recovery up to $97 \%$. This means that a larger amount of thermally treated wood would be required to produce the same unit of energy if used in thermochemical processes. Although this could be undesirable in terms of economics, the high value of the creosote should be more than enough to counter it. Taking into consideration the aforementioned factors involving PAH recovery, solid yield, energy yield, HHV as well as the energy costs associated with an elevated temperature and a subsequent thermochemical process, heating temperatures between 275 and $300{ }^{\circ} \mathrm{C}$ appear to be optimal.

\section{Conclusions}

Thermal desorption of preservative-treated wood is a good alternative technology for the re-use of used wood railroad ties. Our study demonstrates that thermal treatment ranging between 275 and $300{ }^{\circ} \mathrm{C}$ would be optimum to recover preservative to treat new wood tie products in order to offset the cost of the thermal treatment process, and to upgrade the wood quality for use as a feedstock for thermochemical processes such as pyrolysis and gasification to produce chemicals and renewable energy. It could also reduce negative environmental impacts including continuous release of hazardous air pollutants into the environment and emission of greenhouse gases if used wood ties are disposed of in landfills (both the replacement of the fuel with fossil fuel and the 
release of methane). Future work will be conducted to scale up and commercially evaluate a thermal process of used railroad ties and utility poles focussing on both, an auger and fluidized bed reactor system.

\section{Acknowledgements}

The authors would like to thank the support of the 2014-2015 AgResearch Innovation grant (the University of Tennessee Institute of Agriculture), USDA Agriculture and Food Research Initiative (AFRI, Grant \# 2015-6021-24121) and Nisus Corporation (Rockford, TN, USA) for providing the ties for this work. 


\section{References}

[1] USITC. Synthetic organic chemicals. United States production and sales, 1986. Washington, DC: U.S. International Trade Commission; 1987.

[2] Bedient PB, Rodgers AC, Bouvette TC, Tomson MB, Wang TH. Groundwater quality at a creosote waste site. Ground Water. 1984;22:318-29.

[3] Choudhary G, Citra MJ, McDonald AR, Quinones-Rivera A. Toxicological profile for wood creoste, coal tar creosote, coal tar, coal tar pitch, and coal tar pitch volatiles. Atlanta, GA: U.S. Department of health and human services: Public health service agency for toxic substances and disease registry; 2002.

[4] RTA. Basic statistics. In: http://www.rta.org/faqs-main. Railroad Ties Association; 2014.

[5] AWPA. Standard U1-10 Use Category System: User specification for treated wood, In 2010 AWPA Book of Standards. Birmingham2010.

[6] Smith ST. 2014 Railroad tie survey. Helena, MT: Stephen Smith Consulting; 2015.

[7] EPA. Non-Hazardous secondary materials rule makings. U.S. Environmental Protection Agency; 2014.

[8] Bolin CA, Smith ST. Life cycle assessment of creosote-treated wooden railroad crossties in the US with comparisons to concrete and plastic composite railroad crossties. J. Transport. Technol. 2013;3:149-61.

[9] Mazela B. Fungicidal value of wood tar from pyrolysis of treated wood. Waste Management. 2007;27:461-5.

[10] Jung SH, Koo WM, Kim JS. Fast pyrolysis of creosote treated wood ties in a fluidized bed reactor and analytical characterization of product fractions. Energy. 2013;53:33-9.

[11] Labbe N, Ownley BH, Gwinn KD, Moustaid-Moussa N, D'Souza DH. Antimicrobial and anti-inflammatory activity of switchgrass-derived extractives. United States Patent No 9,282,747. USA: University of Tennessee Research Foundation; 2016.

[12] Middaugh DP, Thomas RL, Lantz SE, Heard CS, Mueller JG. Field scale testing of a hyperfiltration unit for removal of creosote and pentachlorophenol from ground water: Chemical and biological assessment. Archives of Environmental Contamination and Toxicology. 1994;26:309-19.

[13] Sipilä K, Kuoppala E, Fagernäs L, Oasmaa A. Characterization of biomass-based flash pyrolysis oils. Biomass Bioenerg. 1998;14:103-13.

[14] Kim P, Weaver S, Noh K, Labbé N. Characteristics of Bio-Oils Produced by an Intermediate Semipilot Scale Pyrolysis Auger Reactor Equipped with Multistage Condensers. Energy Fuels. 2014;28:6966-73.

[15] Bruttel P, Schlink R. Water determination by Karl Fischer titration. Metrohm; 2003.

[16] Yin CY. Prediction of higher heating values of biomass from proximate and ultimate analyses. Fuel. 2011;90:1128-32. 
[17] Bergman PCA, Boersma AR, Kiel JHA, Prins MJ, Ptasinski KJ, Janssen FJJG. Torrefaction for entrained-flow gasification of biomass. Biomass for energy, industry and climate protection: Second World Biomass Conference. Rome, Italy2004. p. 679-82.

[18] Brändli RC, Bucheli TD, Kupper T, Stadelmann FX, Tarradellas J. Optimised accelerated solvent extraction of PCBs and PAHs from compost. International Journal of Environmental Analytical Chemistry. 2006;86:505-25.

[19] Mohan D, Pittman Jr CU, Steele PH. Pyrolysis of wood/biomass for bio-oil: A critical review. Energy Fuels. 2006;20:848-89.

[20] WHO. Coal tar creosote. Geneva, Switzerland: World Health Organization; 2004.

[21] Gevao B, Jones KC. Kinetics and Potential Significance of Polycyclic Aromatic Hydrocarbon Desorption from Creosote-Treated Wood. Environ. Sci. Technol. 1998;32:640-6.

[22] Goyette D, Brooks KM. Creosote evaluation: phase II, Sooke Basin study-baseline to 535 days post construction-1995-1996. Brithsh Columbia, Canada: Environment Canada; 1999.

[23] Zhang X, Yang W, Dong C. Levoglucosan formation mechanisms during cellulose pyrolysis. J. Anal. Appl. Pyrol. 2013;104:19-27.

[24] Mohan D, Pittman CU, Steele PH. Pyrolysis of wood/biomass for bio-oil: A critical review. Energy Fuels. 2006;20:848-89.

[25] Scheirs J, Camino G, Tumiatti W. Overview of water evolution during the thermal degradation of cellulose. Eur Polym J. 2001;37:933-42.

[26] Mamman AS, Lee JM, Kim YC, Hwang IT, Park NJ, Hwang YK, et al. Furfural: Hemicellulose/xylosederived biochemical. Biofuels Bioprod Biorefining. 2008;2:438-54.

[27] Lewis AJ, Ren S, Ye X, Kim P, Labbe N, Borole AP. Hydrogen production from switchgrass via an integrated pyrolysis-microbial electrolysis process. Bioresource Technol. 2015;195:231-41.

[28] Ru B, Wang S, Dai G, Zhang L. Effect of Torrefaction on Biomass Physicochemical Characteristics and the Resulting Pyrolysis Behavior. Energy Fuels. 2015;29:5865-74.

[29] Chen W-H, Peng J, Bi XT. A state-of-the-art review of biomass torrefaction, densification and applications. Renew. Sust. Energ. Rev. 2015;44:847-66.

[30] Wang S, Ru B, Dai G, Lin H, Zhang L. Influence mechanism of torrefaction on softwood pyrolysis based on structural analysis and kinetic modeling. International J. Hydrogen Energy.

[31] Meng J, Park J, Tilotta D, Park S. The effect of torrefaction on the chemistry of fastpyrolysis bio-oil. Bioresource Technol. 2012;111:439-46. 


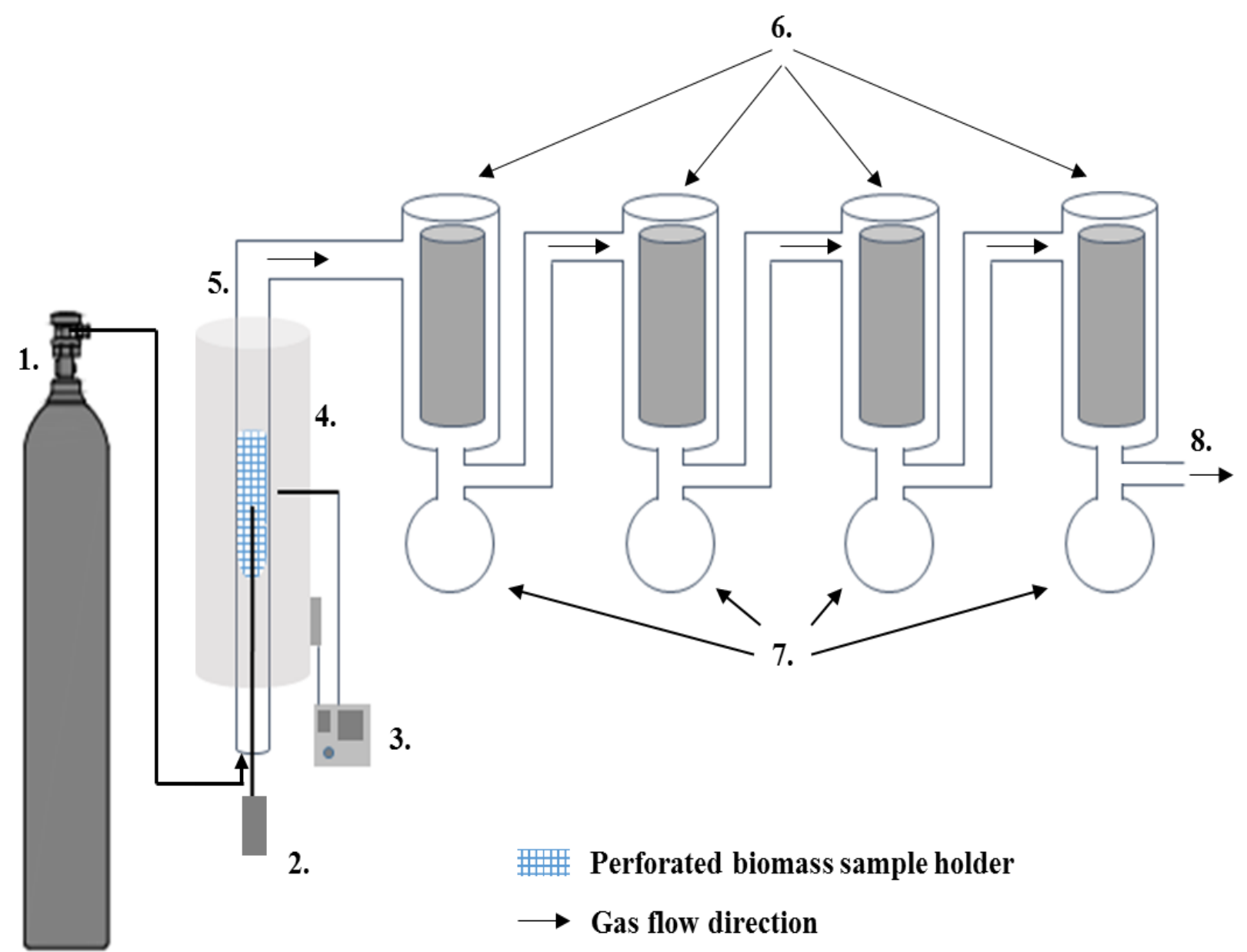

Fig. 1. Schematic representation of the laboratory scale thermal desorption reactor system. $\mathbf{1}$. Nitrogen gas cylinder, 2. Thermocouple measuring biomass bed temperature, 3. Furnace PID controller, 4. Tubular furnace, 5. Quartz tube reactor with porous stainless steel biomass sample holder, 6. Dewar like condensers filled with liquid nitrogen, 7. Liquid sample collection and $\mathbf{8 .}$ Outlet gas port 
Extracted liquid fraction with Dichloromethane (DCM, 250 mL)

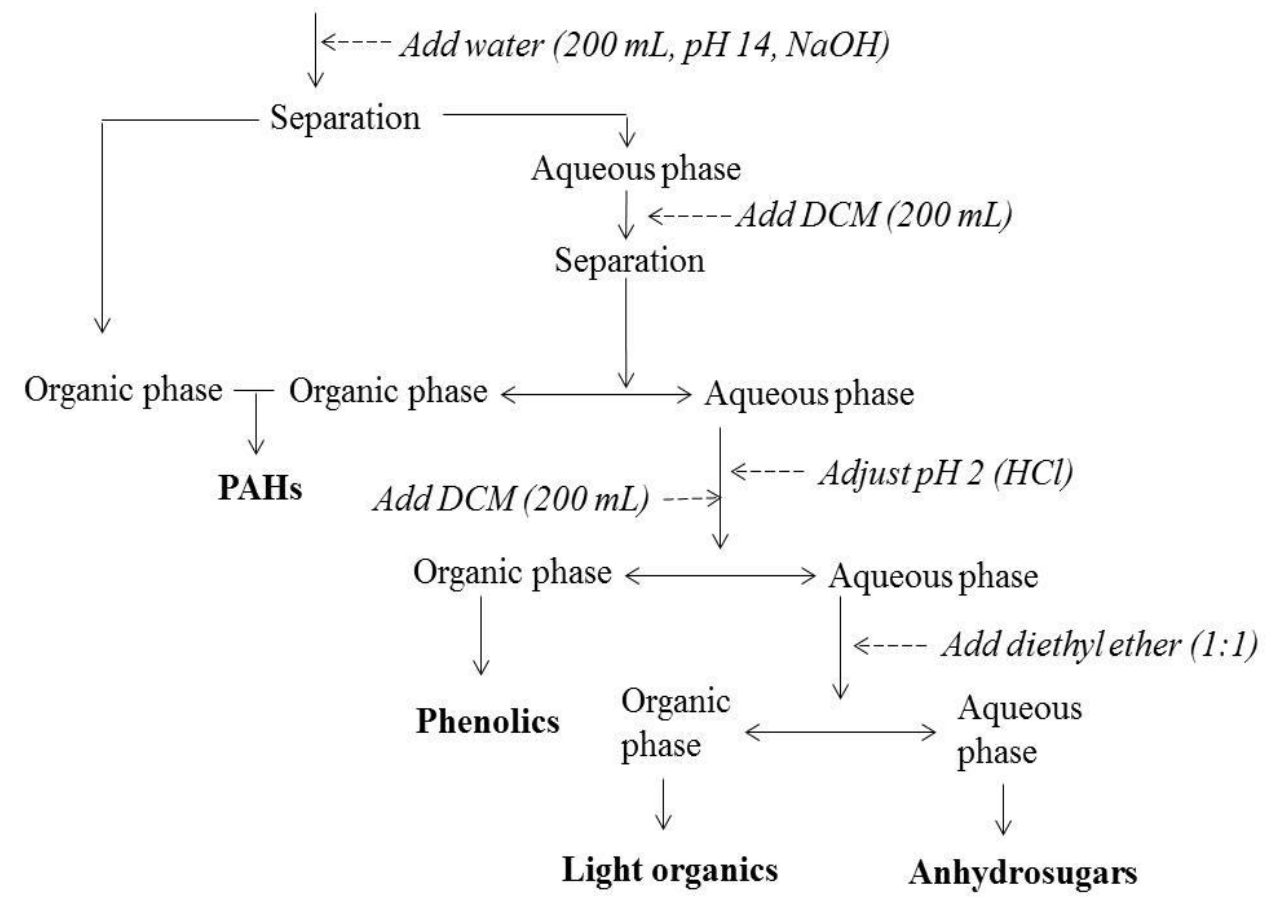

Fig. 2. Solvent fractionation scheme of PAHs and bio-oils. DCM stands for dichloromethane, $\mathrm{NaOH}$ for sodium hydroxide and $\mathrm{HCl}$ for hydrochloric acid. 


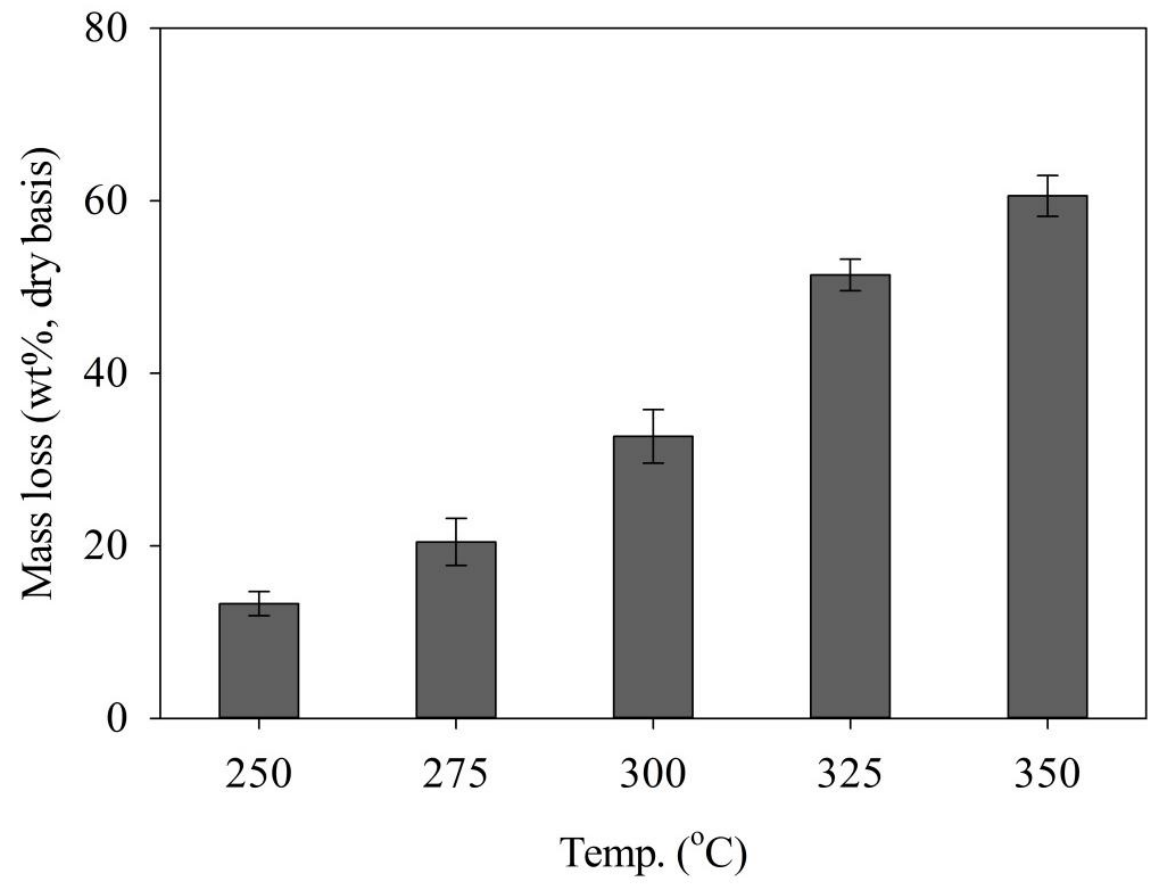

Fig 3. Effect of temperature on mass loss of creosote treated wood tie samples with a 30 min residence time. 


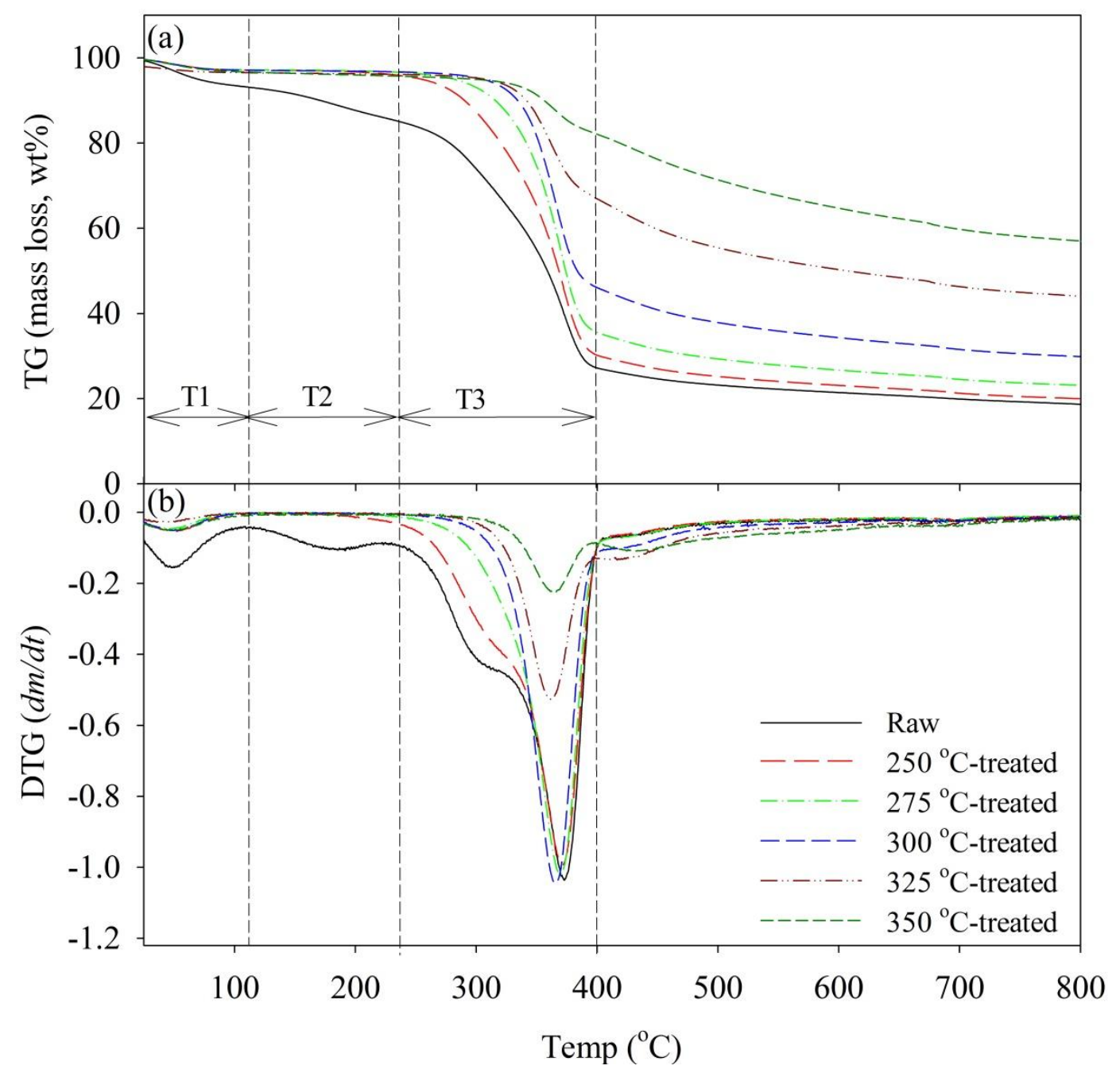

Fig. 4. Thermogravimetric curves of the raw and thermally treated wood tie samples at 250, 275, 300,325 , or $350{ }^{\circ} \mathrm{C}$ for $30 \mathrm{~min}$ residence time. (a) TG thermograms and (b) Derivative TG curves. T1, T2 and $\mathrm{T} 3$ represent temperature regions of 30 to $110{ }^{\circ} \mathrm{C}, 110$ to $235^{\circ} \mathrm{C}$ and 235 to $400{ }^{\circ} \mathrm{C}$, respectively. 

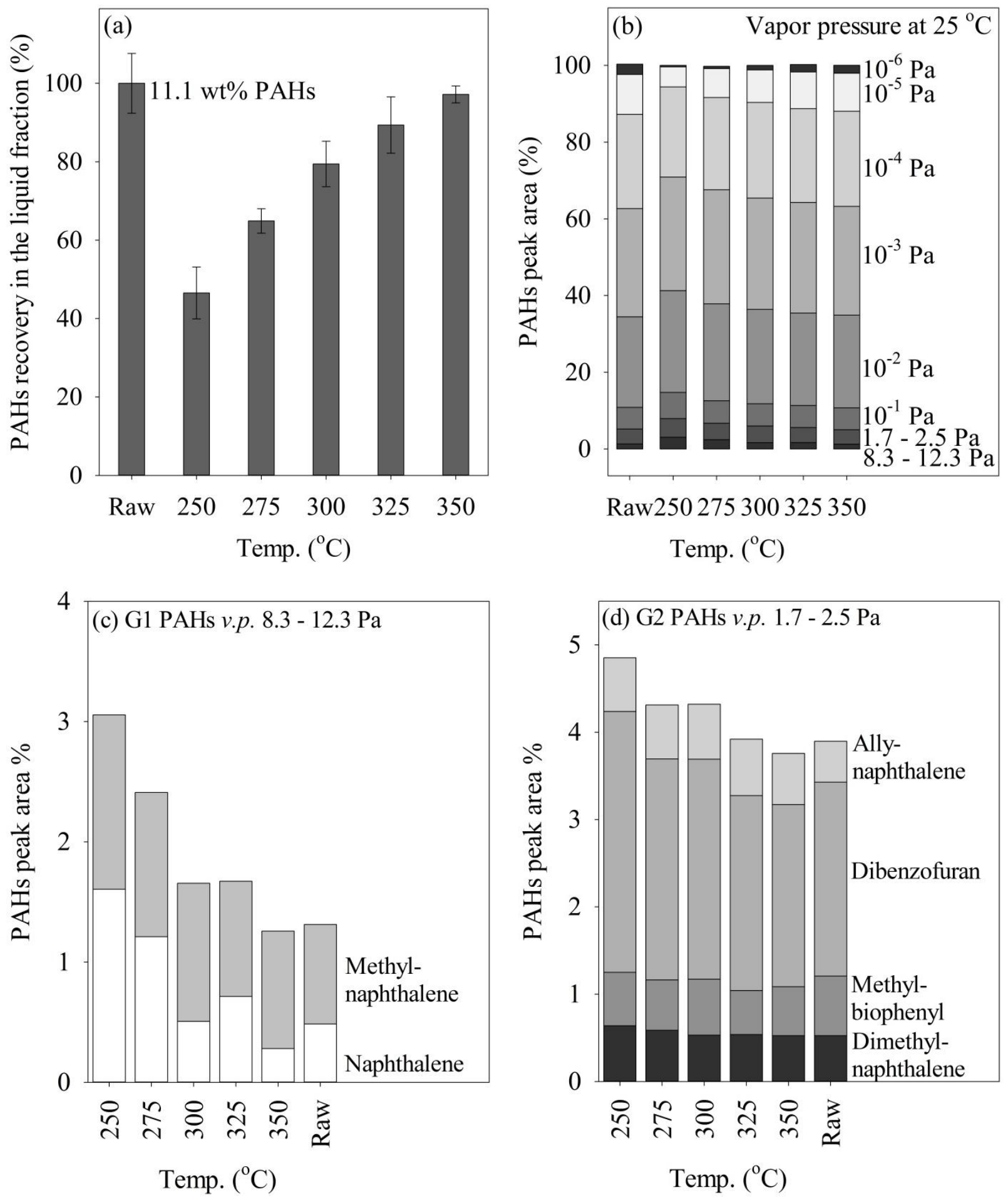


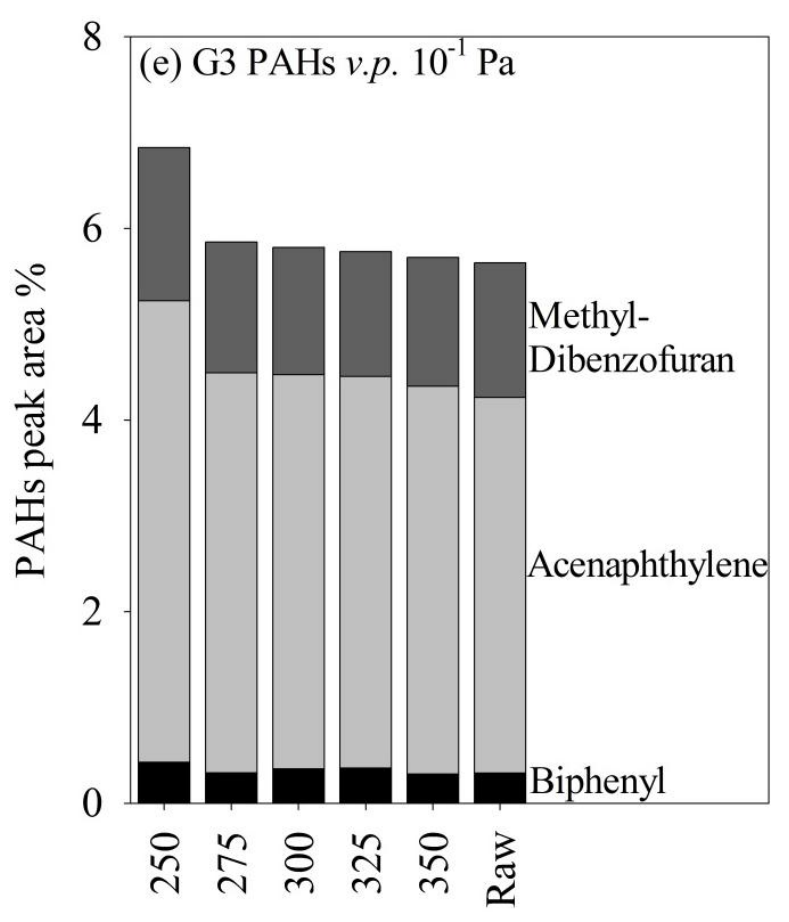

Temp. $\left({ }^{\circ} \mathrm{C}\right)$

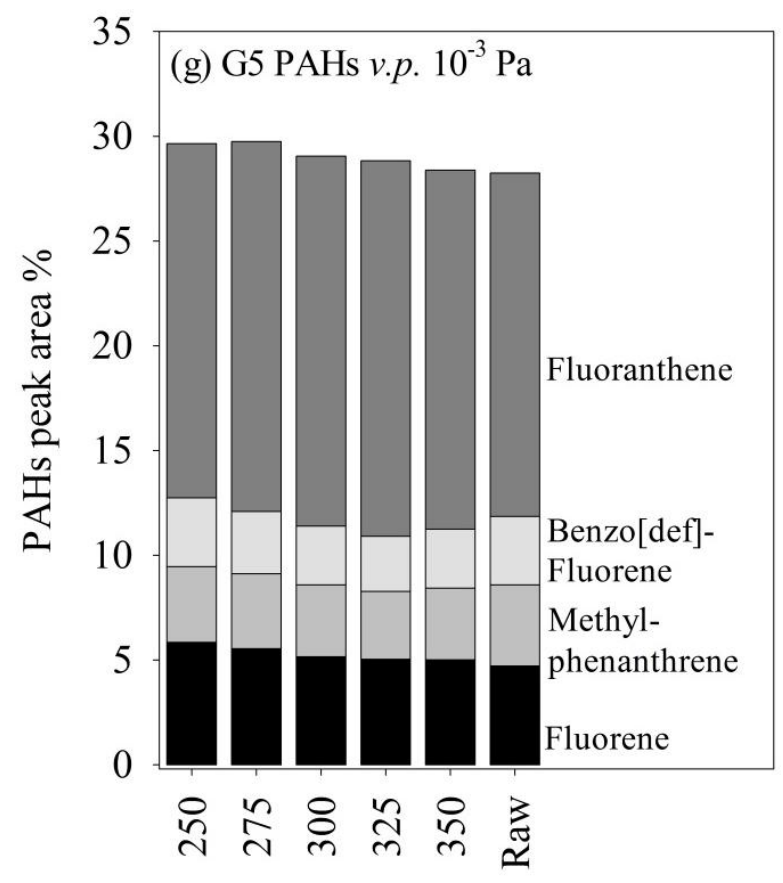

Temp. $\left({ }^{\circ} \mathrm{C}\right)$

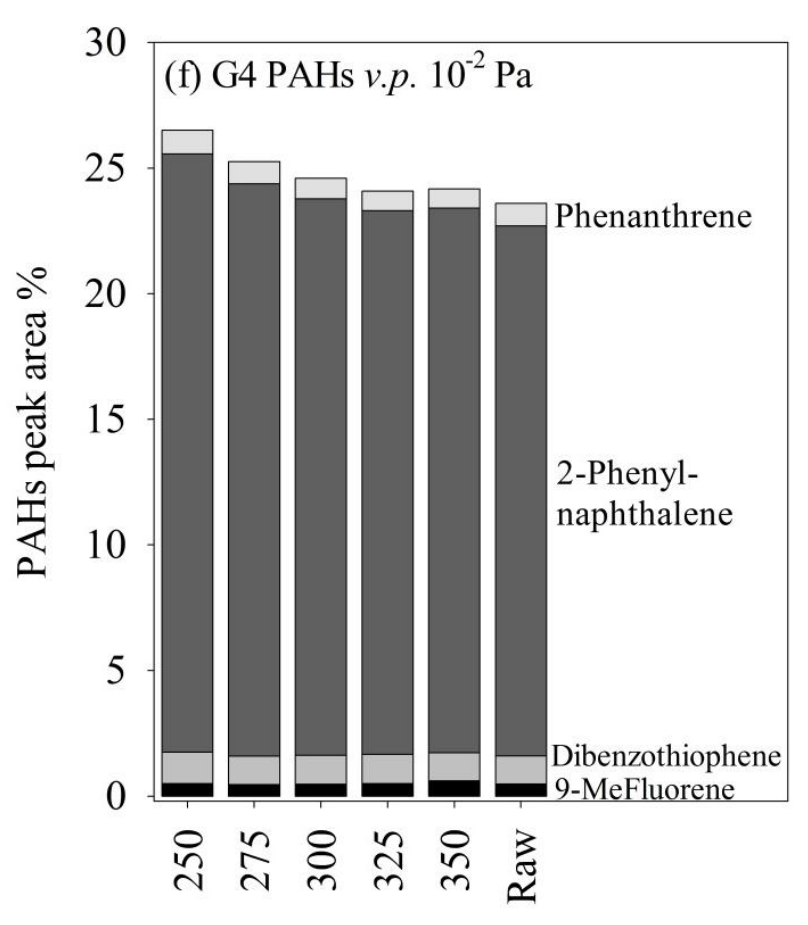

Temp. $\left({ }^{\circ} \mathrm{C}\right)$

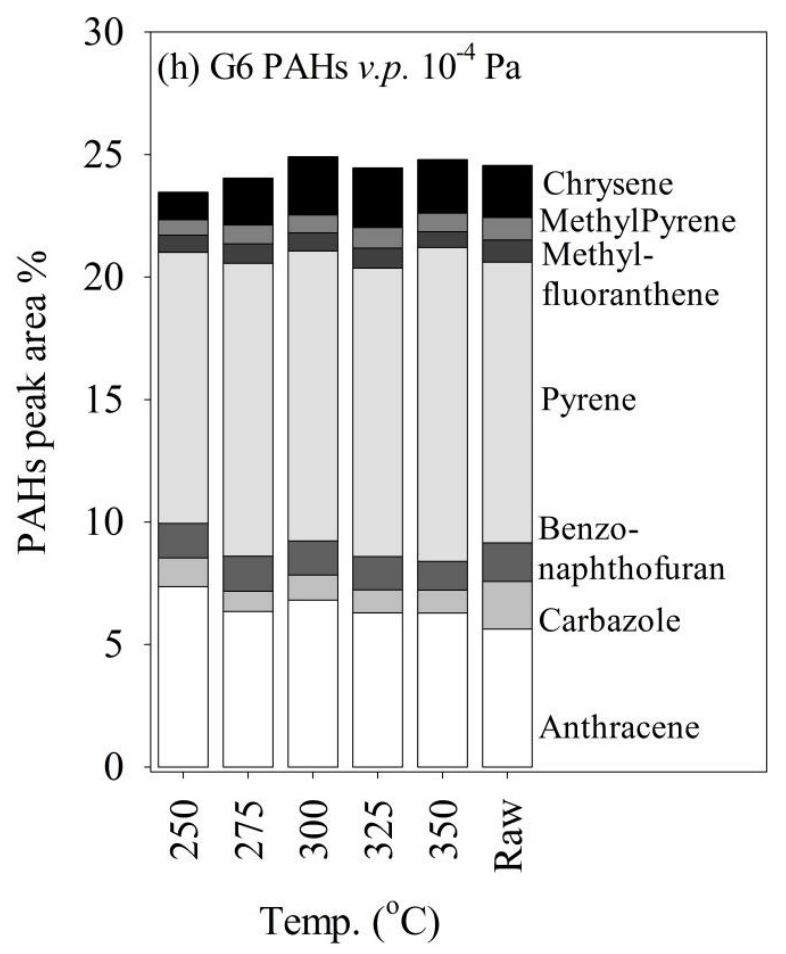




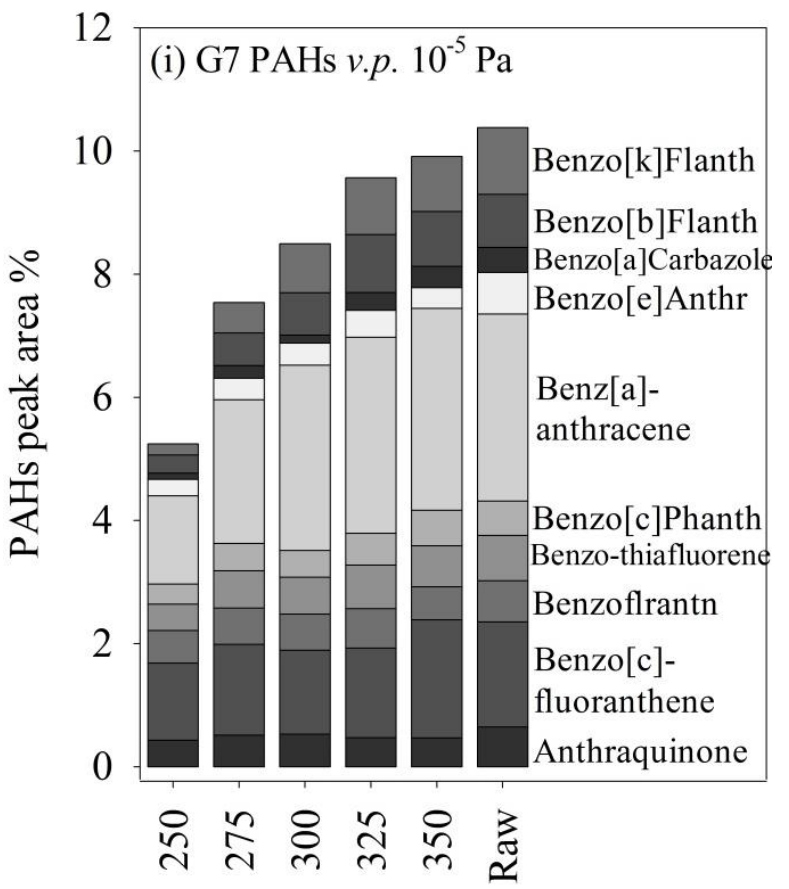

Temp. $\left({ }^{\circ} \mathrm{C}\right)$

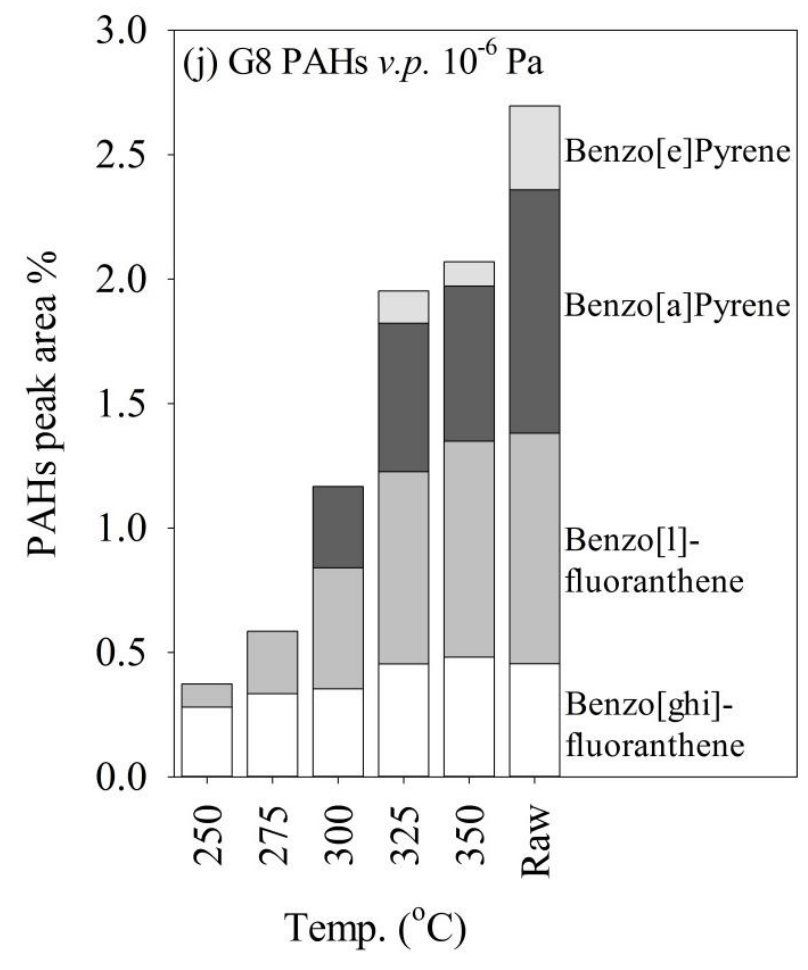

Fig. 5. Yield and GC peak area distribution $\%$ of PAH compounds recovered from the raw and thermally treated wood tie samples at $250,275,300,325$, or $350{ }^{\circ} \mathrm{C}$. (a) Yield of PAH compounds and (b) GC peak area distribution \% of PAHs with various vapor pressures, and (c) (j) distribution of PAH compounds with various vapor pressures. 


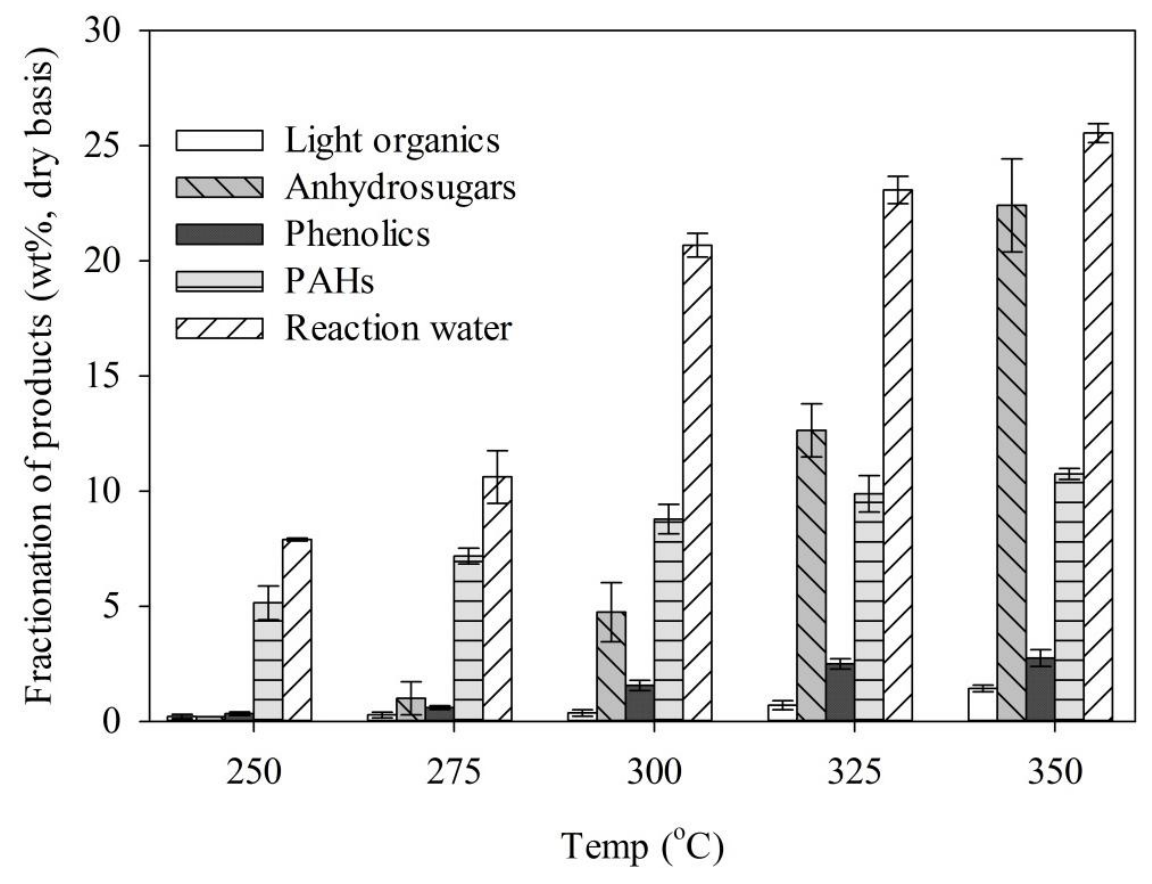

Fig. 6. Fractionation of products in liquid fraction decomposed from creosote-treated wood ties into reaction water, anhydrosugars, phenolics, light organics and furans. 

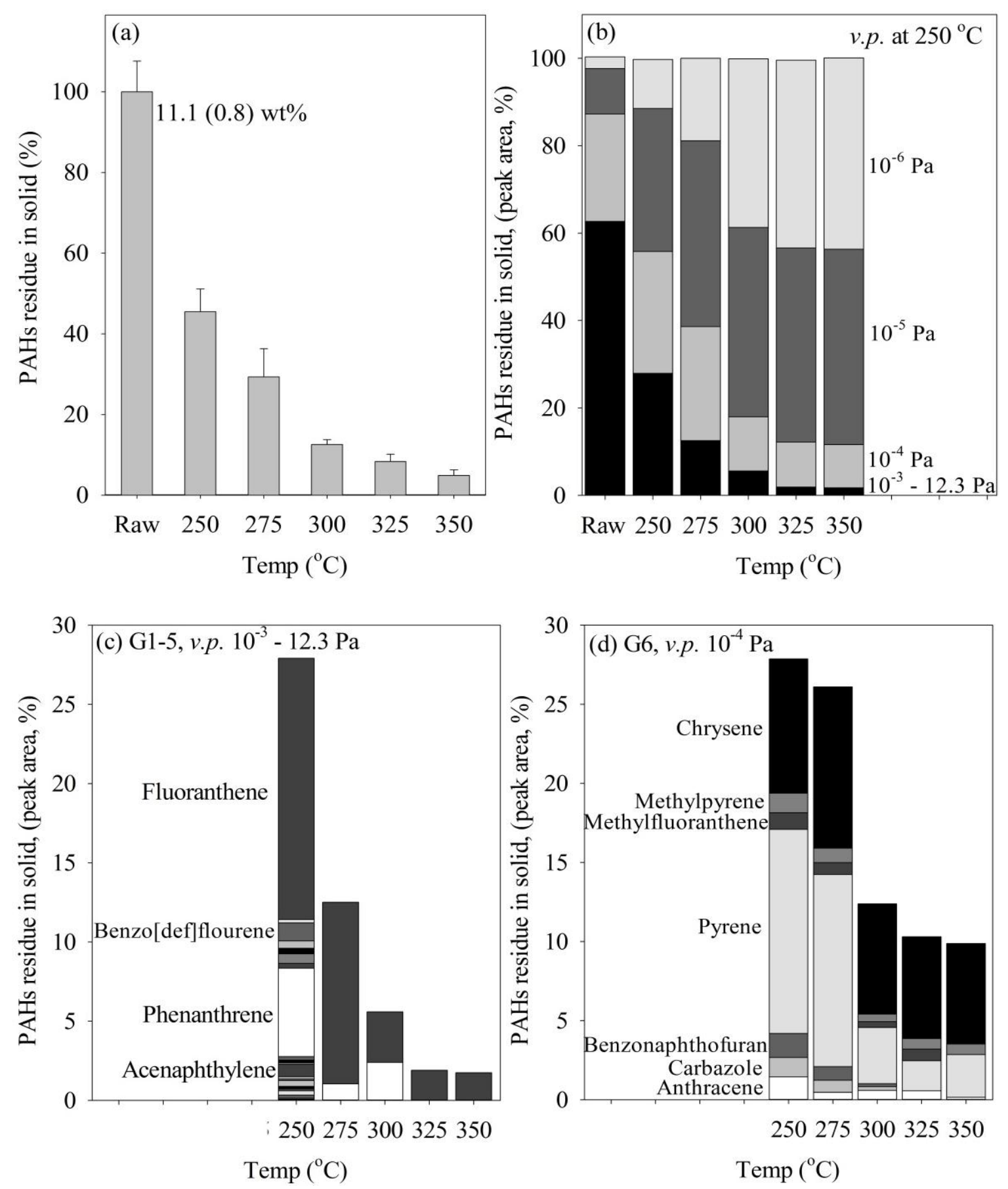

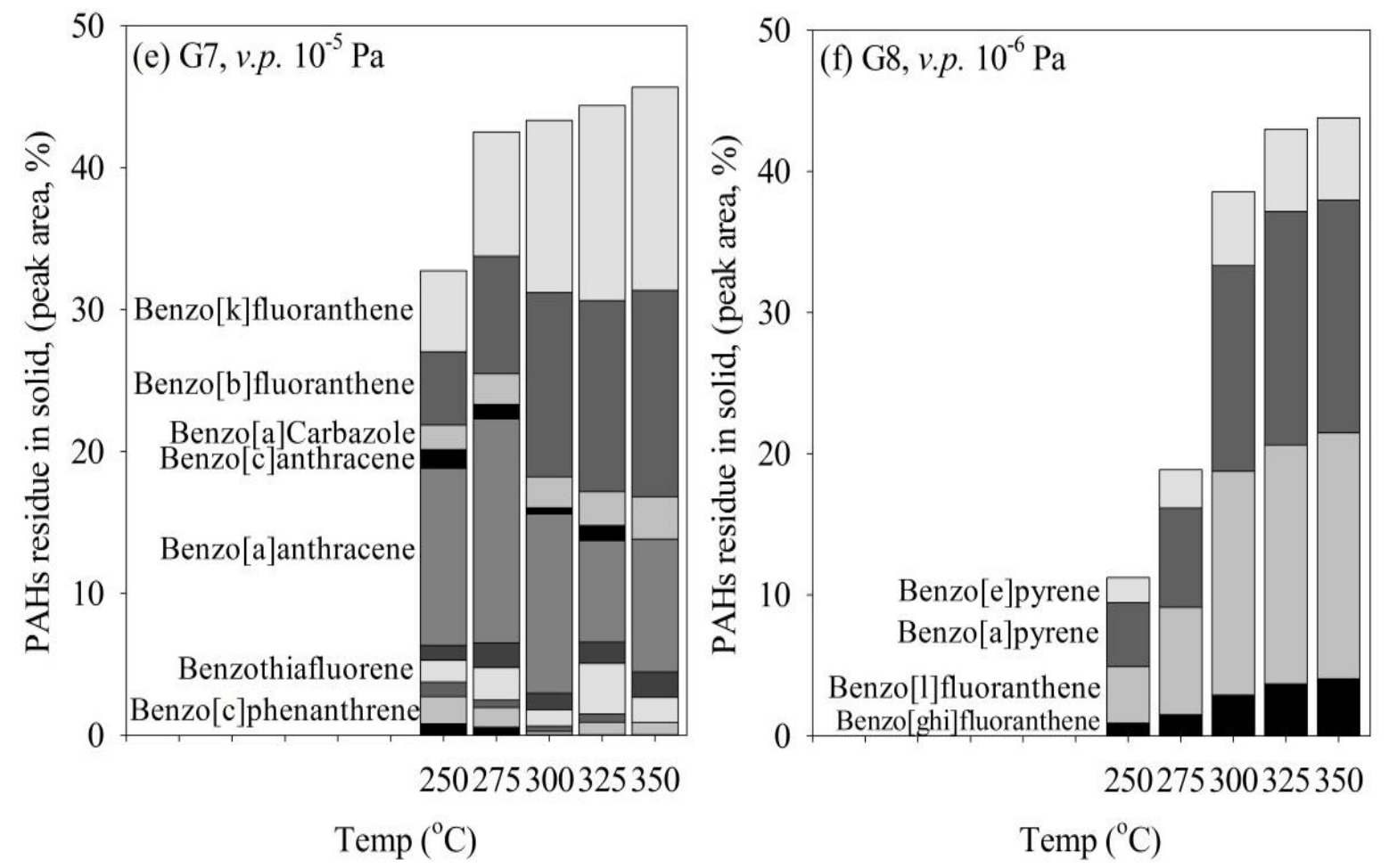

Fig. 7. PAHs residues in the thermally treated wood tie samples. (a) PAHs residue (\%) in solid and $(\mathrm{b}-\mathrm{f}$ ) distribution (peak area \%) of PAHs compounds with various vapor pressures remaining in the thermally treated wood tie samples. 

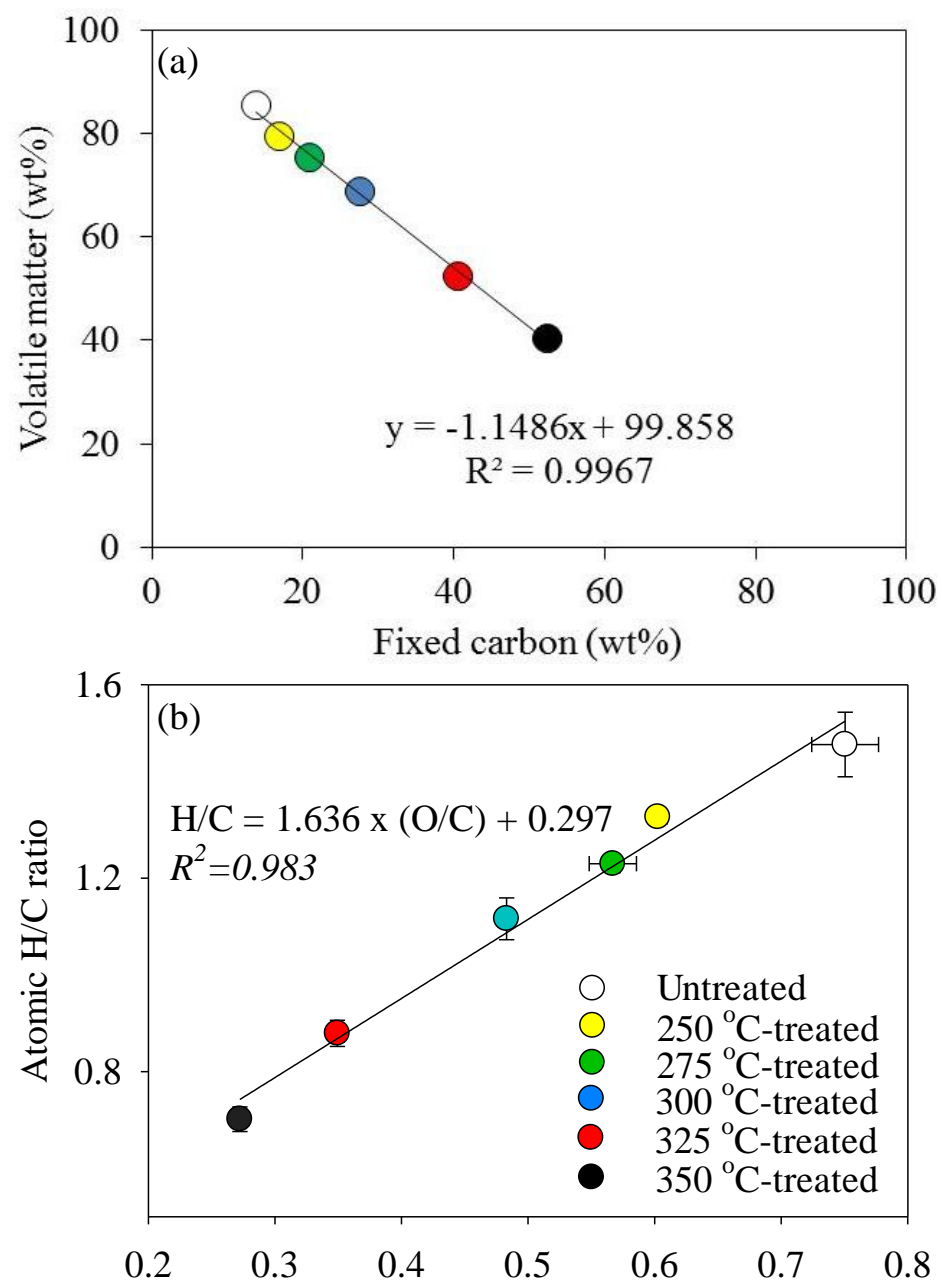

Atomic $\mathrm{O} / \mathrm{C}$ ratio

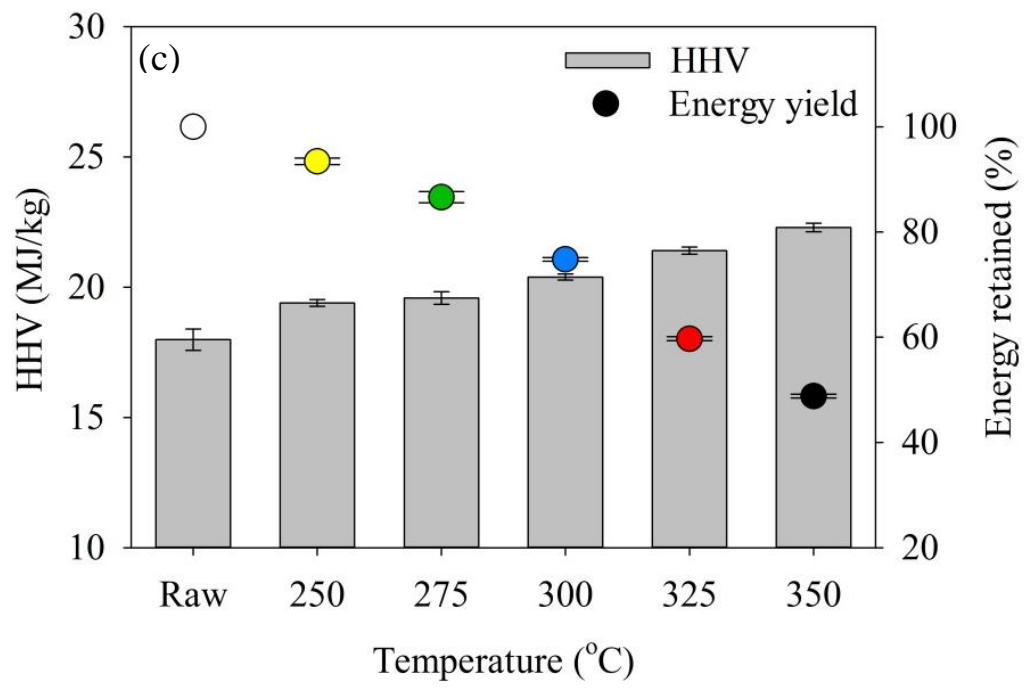

Fig. 8. Proximate and ultimate analysis of the wood tie sample treated at 250, 275, 300, 325, or 350 C. (a) Proximate analysis, (b) Van-Krevelen diagram, and (c) Higher heating value (HHV) and energy retained. 


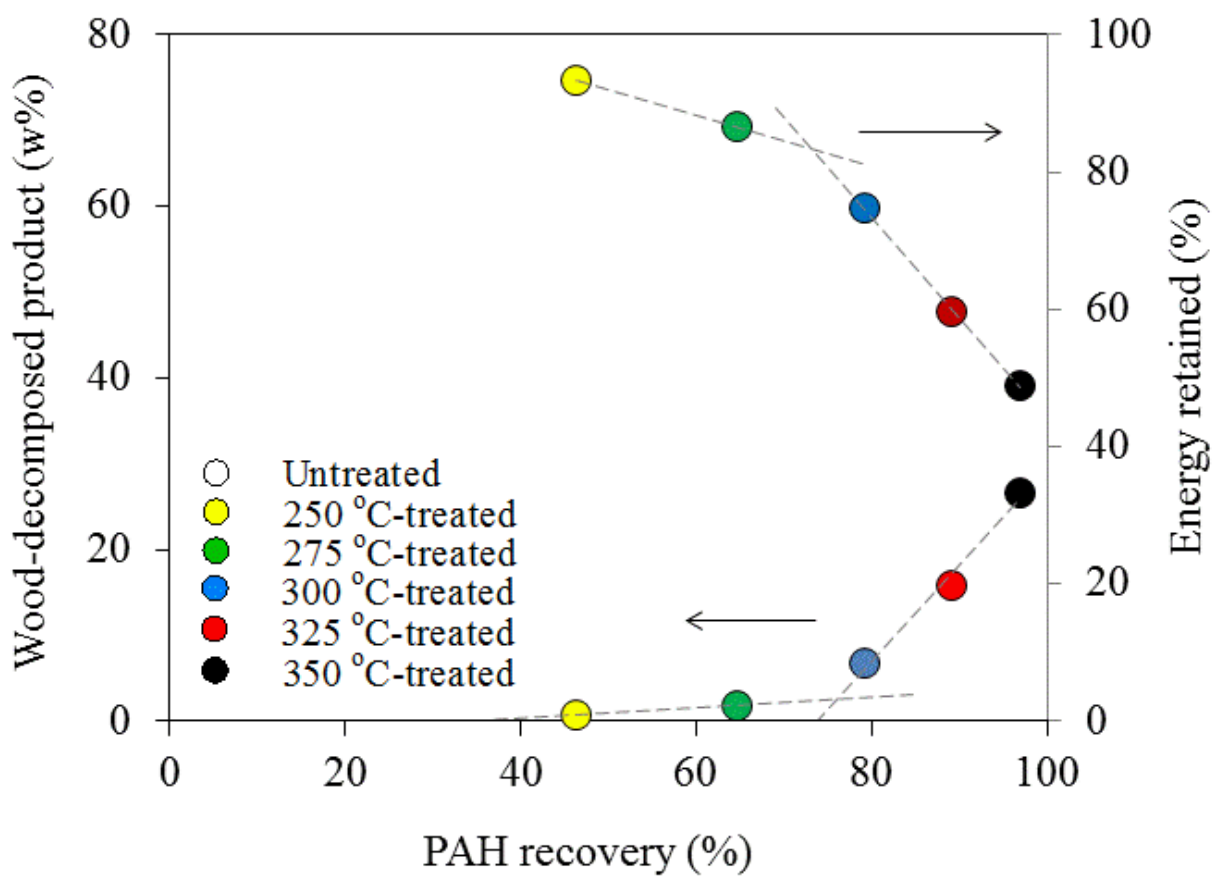

Fig. 9. Correlations between products from different thermal treatments. (a) PAHs recovery vs mass loss of wood tie, (b) PAHs recovery vs wood component in liquid fraction, and (c) PAH s recovery vs energy retained (\%). 
Table 1. Proximate and ultimate analysis of the raw and thermally treated wood tie samples at temperature ranging from 250 to $350{ }^{\circ} \mathrm{C}$.

\begin{tabular}{lcccccccccc}
\hline \multirow{2}{*}{ Sample } & \multicolumn{2}{c}{$\begin{array}{c}\text { Moisture } \\
\text { (wt \% dry basis) }\end{array}$} & \multicolumn{3}{c}{$\begin{array}{c}\text { Proximate analysis } \\
\text { (wt \% dry basis) }\end{array}$} & \multicolumn{4}{c}{$\begin{array}{c}\text { Ultimate analysis } \\
\text { (wt \% dry basis) }\end{array}$} \\
\cline { 2 - 11 } & KFT $^{1}$ & ASTM $^{2}$ & VM & Ash & $\mathrm{FC}^{3}$ & $\mathrm{C}$ & $\mathrm{H}$ & $\mathrm{N}$ & $\mathrm{O}$ \\
\hline \multirow{2}{*}{ Raw } & 6.5 & 8.1 & 85.5 & 1.4 & 13.7 & 46.6 & 5.7 & 0.2 & 46.0 \\
& $(0.1)$ & $(0.3)$ & $(0.6)$ & $(0.1)$ & $(0.6)$ & $(0.7)$ & $(0.2)$ & $(0.0)$ & $(0.9)$ \\
$250{ }^{\circ} \mathrm{C}$ & 2.9 & 3.6 & 79.4 & 3.7 & 16.9 & 50.2 & 5.3 & 0.1 & 40.4 \\
& $(0.2)$ & $(0.2)$ & $(0.7)$ & $(0.7)$ & $(0.7)$ & $(0.2)$ & $(0.1)$ & $(0.1)$ & $(0.3)$ \\
$275{ }^{\circ} \mathrm{C}$ & 2.2 & 3.0 & 75.2 & 3.9 & 20.8 & 51.6 & 5.3 & 0.2 & 39.0 \\
& $(0.3)$ & $(0.4)$ & $(0.8)$ & $(0.1)$ & $(0.8)$ & $(0.7)$ & $(0.1)$ & $(0.0)$ & $(0.7)$ \\
$300{ }^{\circ} \mathrm{C}$ & 3.0 & 3.3 & 68.8 & 3.6 & 27.5 & 54.9 & 5.1 & 0.2 & 35.3 \\
& $(0.2)$ & $(0.4)$ & $(0.8)$ & $(0.1)$ & $(0.7)$ & $(0.3)$ & $(0.2)$ & $(0.1)$ & $(0.3)$ \\
$325{ }^{\circ} \mathrm{C}$ & 2.2 & 2.5 & 52.8 & 7.0 & 40.5 & 60.2 & 4.4 & 0.3 & 28.1 \\
& $(0.2)$ & $(0.4)$ & $(1.1)$ & $(0.3)$ & $(1.2)$ & $(0.2)$ & $(0.1)$ & $(0.0)$ & $(0.3)$ \\
$350{ }^{\circ} \mathrm{C}$ & 3.2 & 3.5 & 40.3 & 7.3 & 52.5 & 65.0 & 3.8 & 0.3 & 23.6 \\
& $(0.2)$ & $(0.3)$ & $(0.4)$ & $(0.1)$ & $(0.4)$ & $(0.3)$ & $(0.1)$ & $(0.0)$ & $(0.4)$ \\
\hline
\end{tabular}

$\mathrm{VM}, \mathrm{FC}, \mathrm{C}, \mathrm{H}, \mathrm{N}$ and $\mathrm{O}$ stand for volatile matter, fixed carbon, carbon, hydrogen, nitrogen and oxygen.

${ }^{1)}$ Moisture content was determined by Karl Fischer titration.

${ }^{2)}$ moisture was determined according to the ASTM standard.

3) fixed carbon and was determined by difference.

4) Oxygen content was determined by difference.

Numbers in the parentheses represent standard deviations. 
Table 2. Organic compounds identified in the liquid fraction produced from raw and thermally treated tie samples.

\begin{tabular}{|c|c|c|c|c|c|c|c|}
\hline & $\begin{array}{c}\mathrm{RT} \\
(\mathrm{min})\end{array}$ & Compounds & Group & No. & $\begin{array}{c}\mathrm{RT} \\
(\mathrm{min})\end{array}$ & Compounds & Group \\
\hline 1 & 6.6 & Glycolaldehyde & a) Ald & 38 & 34.5 & 4-Methyldibenzofuran & Fur \\
\hline 2 & 7.4 & Acetic acid & Acid & 39 & 34.9 & 3,5-Dimethoxyacetophenone & PAH \\
\hline 3 & 8.4 & Hydroxyacetone & ${ }^{\text {a) }}$ Ket & 40 & 35.0 & 4-Methyldibenzofuran & $\mathrm{PAH}$ \\
\hline 4 & $10.3 \mathrm{I}$ & Propanoic acid & Acid & 41 & 35.3 & Methoxyeugenol & Lig \\
\hline 5 & 11.2 & 1-Hydroxy-2-butanone & Ket & 42 & 36.5 & 9-Methylfluorene & $\mathrm{PAH}$ \\
\hline 6 & 11.3 & Acetoxyacetic acid & Acid & 43 & 37.6 & Levoglucosan & AnS \\
\hline 7 & $12.0 \mathrm{I}$ & Dimethoxytetrahydrofuran & ${ }^{\mathrm{a}}$ Fur & 44 & 37.8 & Methoxyeugenol & Lig \\
\hline 8 & $12.7 \mathrm{I}$ & Methyl pyruvate & ${ }^{a)}$ Est & 45 & 38.3 & Dibenzothiophene & $\mathrm{PAH}$ \\
\hline 9 & $13.1 \mathrm{I}$ & Dimethoxytetrahydrofuran & Fur & 46 & 39.0 & Phenanthrene & $\mathrm{PAH}$ \\
\hline 10 & $13.3 \mathrm{I}$ & Furfural & Fur & 47 & 39.1 & Anthracene & PAH \\
\hline 11 & 14.9 & Acetol acetate & Est & 48 & 40.7 & Desaspidinol & Lig \\
\hline 12 & 15.5 & (2-Hydroxy-1-methoxy)ethylfuran & Fur & 49 & 41.1 & 1-Methylphenanthrene & PAH \\
\hline 13 & 17.02 & 2-Hydroxy-2-cyclopenten-1-one & Ket & 50 & 41.2 & 2-Methylphenanthrene & PAH \\
\hline 14 & 17.75 & 5-Methylfurfural & Fur & 51 & 41.6 & Benzo[def]fluorine & $\mathrm{PAH}$ \\
\hline 15 & 17.9 & 1-Acetoxy-2-butanone & Ket & 52 & 41.8 & 3-Methylphenanthrene & $\mathrm{PAH}$ \\
\hline 16 & 18.72 & 2(5H)-Furanone & Fur & 53 & 42.4 & 2-Phenylnaphthalene & $\mathrm{PAH}$ \\
\hline 17 & 19.6 & 1,1-Dimethoxyhexane & 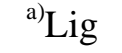 & 54 & 42.6 & Carbazole & $\mathrm{PAH}$ \\
\hline 18 & 20.13 & 3-Methyl-1,2-cyclopentanedione & & 55 & 43.6 & Anthraquinone & PAH \\
\hline 19 & 21.5 & o-Guaiacol & Lig & 56 & 44.8 & Fluoranthene & $\mathrm{PAH}$ \\
\hline 20 & $23.2 \mathrm{I}$ & Naphthalene & ${ }^{\mathrm{b})} \mathrm{PAH}$ & 57 & 45.6 & Benzonaphthofuran & PAH \\
\hline 21 & 24.41 & Homoguaiacol & Lig & 58 & 45.8 & Pyrene & PAH \\
\hline 22 & 26.2 & 1-Methylnaphthalene & PAH & 59 & 46.9 & 2-Methylfluoranthene & $\mathrm{PAH}$ \\
\hline 23 & 26.72 & 2-Methylnaphthalene & PAH & 60 & 47.3 & Benzo[c]fluorine & $\mathrm{PAH}$ \\
\hline 24 & 27.7 & 1,4:3,6-Dianhydro- $\alpha$-d-glucopyranose & a) AnS & 61 & 47.6 & 2,3-Benzofluorene & $\mathrm{PAH}$ \\
\hline 25 & 28.2 & 4-Vinylguaiacol & Lig & 62 & 47.8 & 1-Methylpyrene & PAH \\
\hline 26 & $28.4 \mathrm{I}$ & Biphenyl & PAH & 63 & 50.4 & 3,4-Benzo-9-thiafluorene & $\mathrm{PAH}$ \\
\hline 27 & 29.5 & 1,7-Dimethylnaphthalene & PAH & 64 & 50.5 & Benzo[c]phenanthrene & PAH \\
\hline 28 & 29.62 & 2,6-Dimethylnaphthalene & $\mathrm{PAH}$ & 65 & 50.8 & Benzo[ghi]fluoranthene & PAH \\
\hline 29 & 30.1 & 1,4-Dimethylnaphthalene & PAH & 66 & 51.8 & Chrysene & $\mathrm{PAH}$ \\
\hline 30 & 31.02 & 4-Methylbiphenyl & PAH & 67 & 52.0 & Benz[a]anthracene & PAH \\
\hline 31 & 31.4 & Acenaphthylene & PAH & 68 & 52.2 & 3,4-Benzophenanthrene & PAH \\
\hline 32 & $31.5 \mathrm{l}$ & Isoeugenol & Lig & 69 & 55.3 & Benzo[a]carbazole & $\mathrm{PAH}$ \\
\hline 33 & 31.8 & 4-Methoxy-3-(methoxymethyl)phenol & Lig & 70 & 59.7 & Benzo[b]fluoranthene & PAH \\
\hline 34 & 32.41 & Dibenzofuran & PAH & 71 & 59.9 & Benzo[k]fluoranthene & PAH \\
\hline 35 & 33.65 & 5-tert-Butylpyrogallol & Lig & 72 & 62.2 & Benzo[1]fluoranthene & $\mathrm{PAH}$ \\
\hline 36 & $34.0 \mathrm{I}$ & Fluorene & PAH & 73 & 62.7 & Benzo[a]pyrene & PAH \\
\hline 37 & 34.1 & 1-Allylnaphthalene & PAH & 74 & 63.8 & 4,5-Benzopyrene & $\mathrm{PAH}$ \\
\hline
\end{tabular}

a) Ald stands for aldehyde, Est for ester, Ket for ketone, Fur for furan, Lig for lignin, AnS for anhydrosugars. ${ }^{\text {b) }} \mathrm{PAH}$ represents polycyclic aromatic hydrocarbons (PAHs). 